\title{
Brominated Flame Retardants and Seafood Safety: A review
}

Rebeca Cruz, Sara C. Cunha* and Susana Casal

*Corresponding author:

Sara C. Cunha: Tel: +351-220428639; Fax: +351-226093390; E-mail: sara.cunha@ff.up.pt.

REQUIMTE, Laboratório de Bromatologia e Hidrologia, Faculdade de Farmácia, Universidade do Porto, Rua de Jorge Viterbo Ferreira 228, 4050-313 Porto, Portugal. 


\begin{abstract}
Brominated flame retardants (BFRs), frequently applied to industrial and household products to make them less flammable, are highly persistent in the environment and cause multi-organ toxicity in human and wildlife. Based on the review of BFRs presence in seafood published from 2004 to 2014 , it is clear that such pollutants are not ideally controlled as the surveys are too restricted, legislation inexistent for some classes, the analytical methodologies diversified, and several factors as food processing and eating habits are generally overlooked. Indeed, while a seafood rich diet presents plenty of nutritional benefits, it can also represent a potential source of these environmental contaminants. Since recent studies have shown that dietary intake constitutes a main route of human exposure to BFRs, it is of major importance to review and enhance these features, since seafood constitutes a chief pathway for human exposure and biomagnification of priority environmental contaminants. In particular, more objective studies focused on the variability factors behind contamination levels, and subsequent human exposure, are necessary to support the necessity for more restricted legislation worldwide.
\end{abstract}

KEYWORDS: Brominated Flame Retardants; Polybrominated Diphenyl Ethers; Contaminants; Seafood; Food Safety 


\section{INTRODUCTION}

Seafood is one of the most important food commodities worldwide, both from economical and nutritional point of view, with Europe as the leading continent in seafood consumption (FAOSTAT, 2013). Regardless the health benefits of a seafood rich diet, which have been extensively recognized (Loret, 2010), it can also be a source of pernicious environmental contaminants, thereby providing a major pathway for human exposure and biomagnification (Marques et al., 2011). Therefore, several governmental and health authorities became highly concerned with seafood quality and safety, increasing regulation for specific contaminants and supporting the development of specific actions regarding major sea-related challenges. The assessment of safety issues related to non-regulated priority contaminants and the evaluation of their impact on public health and environment has become mandatory.

In order to define the priority pollutants and strategic actions, Rotterdam Convention, assembled in 1998, aimed to define guidelines for the import and use monitoring of 14 hazardous chemicals (RC, 1998). Currently, there are a total of 47 substances (33 pesticides and 14 industrial chemicals) under Rotterdam Convention surveillance (RC, 2011).

Furthermore, the Stockholm Convention on Persistent Organic Pollutants (POPs) was assembled in 2001, under the management of the United Nations Environment Program. As a result, a list of the 12 worst pollutants was laid down in 2006, known as the "Dirty Dozen" (SCPOP, 2006), which was further updated with 10 new contaminants (SCPOP, 2009, 2011).

As to the marine environment, and in accordance with the European Union (EU) Marine Strategy Framework Directive (MSFD) (Directive 2008/56/EC) adopted in 2008, the "Priority Contaminants" concept embraces all harmful contaminants in seafood that might constitute a risk for human health and for which there is insufficient scientific knowledge. It includes substances for which no maximum levels have been laid down yet (in EU legislation or international standards), as well as substances for which maximum levels have been provided but require revision. In 2010, the MSFD group 9, compiled the regulatory levels for some substances, including heavy metals (lead, cadmium and mercury), polycyclic aromatic hydrocarbons, polychlorinated dibenzo-p-dioxins, polychlorinated dibenzofurans, dioxin-like polychlorinated biphenyls (PCBs), and radionuclides, and established 
seven classes of compounds as chief priority contaminants, ordered according to priority as: 1) Nondioxin-like polychlorinated biphenyls (congeners \#28, 52, 101, 138, 153 and 180); 2) Brominated flame retardants (BFR); 3) Polyfluorinated compounds; 4) Arsenic (total and inorganic); 5) Organotincompounds (tributyltin, triphenyltin, dibutyltin); 6) Organochlorine pesticides (chlordane, dichlorodiphenyltrichloroethane, dicofol, endosulfan, heptachlor, aldrin, dieldrin, endrin, hexachlorocyclohexane, toxaphene, hexachloro-benzene), and 7) Phthalates (benzylbutylphthalate, dibutyl phthalate, di-2-ethylhexyl phthalate, diisodecyl phthalate, diisononyl phthalate, diisobutyl phthalate) (Swartenbroux et al., 2010). Since non-dioxin-like PCBs are already being regulated and thoroughly monitored (ECR, 2001; 2006a, 2011, 2012a), BFRs rise first on the list as priority contaminants. The lack of regulation and monitoring of these pollutants in seafood makes their assessment urgent and imperative.

BFRs are chemicals commonly added for many years to a wide variety of industrial and household products to improve their fire resistance, and include diverse chemical classes of compounds. Their widespread existence in the environment, even in locations far from where they were produced or used, as well as their presence in human and wildlife organisms raised an increased concern worldwide (Chen et al., 2011; Goutte et al., 2013). Unfortunately, few data exist on the presence of BFRs in humans and its toxic effects. Notwithstanding, for some classes, as polybrominated diphenyl ethers (PBDEs), effects on the neurological and thyroid hormone systems, sexual hormones and reproduction have been shown in rodents (Chen et al., 2012b; Lee et al., 2012; Williams et al., 2013). There are also indications that hexabromocyclododecanes (HBCDDs) exposure can affect liver hormone system, and might cause neurobehavioral alterations (Deng et al., 2009; Feng et al., 2013a), while tetrabromobisphenol A (TBBPA) has also been shown to have effects on thyroid hormones, neurological function, and reproduction (Chan and Chan, 2012; Huang et al., 2013).

Hence, in 2002, Directive 2002/96/EC on waste electrical and electronic equipment (WEEE) requires that plastic containing BFRs has to be removed from any separately collected WEEE and treated aside (ED, 2003). In addition, in 2010 diverse amendments of the original European Union Regulation $N^{\circ}$ 850/2004 (ECR, 2004) entered into force, apart from few parties, and new chemicals were added, including few BFRs, namely four PBDEs (Tetra-, Penta-, Hexa- and Hepta-PBDEs) and 
hexabromobiphenyl (ECR, 2010a, 2010b). Afterwards, the $8^{\text {th }}$ Persistent Organic Pollutants Review Committee (POPRC) proposed also the inclusion of total HBCDDs in Annex A of the Convention (SCPOP, 2012).

According to the European Food Safety Agency (EFSA), the following BFRs classes were defined in 2012 as the most relevant in terms of toxicological effects and prevalence, thus being the main focus of the present review: 1) PBDEs; 2) Polybrominated biphenyls (PBBs); 3) Hexabromocyclododecanes; 4) Hexabromobenzene (HBB); 5) TBBPA and other phenols, as Tribromophenol (TBP); 6) Decabromodiphenyl ethane (DBDPE); and 7) 1,2-Bis(2,4,6tribromophenoxy)ethane (BTBPE) (EFSA, 2011a). Nevertheless, there are many other BFRs which are not regulated, and even for those which are, there are still concerns regarding the potential risks they carry to public health due to their persistence in the environment.

Being present in residual levels, a wide range of extraction and clean-up techniques, together with different analytical instruments, have been studied for identifying and quantifying BFRs in both biotic and abiotic matrices. This subject has been the focus of several review papers over the last few years (Mas et al., 2010; Covaci et al., 2011; Papachlimitzou et al., 2012; Dirtu et al., 2013; Xu et al., 2013).

Aware that seafood is a major dietary route for human exposure to these widespread contaminants, the main purpose of the present review is to summarize the actual status of seafood consumption and levels of the aforementioned BFR classes, their major sources, environmental fate as well as ongoing legislation and future needs.

\section{THE STATUS OF WORLD'S FISHERIES AND SEAFOOD CONSUMPTION}

Seafood is one of the most important food commodities. Herein, seafood is used in accordance with European Regulation № 853/2004 (ECR, 2004), which states that: "seafood comprises fishery products and live bivalve molluscs, and no distinction is made between products coming from the sea and other sources, nor between wild catch and aquaculture species". On the other hand, fishery products include "all seawater or freshwater animals (except for live bivalve molluscs, live 
echinoderms, live tunicates and live marine gastropods, and all mammals, reptiles and frogs) whether wild or farmed, and including all edible forms, parts and products of such animals" (ECR, 2004). According to average catches from 2005 to 2009, the Northwest Pacific area is the largest contributor to global supply (25\%), followed by Southeast Pacific (16\%) and Western Central Pacific (14\%), while the sixteen remaining marine fishing areas comprise $45 \%$ of average catches (FAO, 2011). In 2011, the highest caught groups at the global level were: 1) Herrings, sardines, anchovies (11.5\%); 2) Tunas, bonitos, billfishes (7.3\%), and 3) Cods, hakes, haddocks (6.9\%) (FAO, 2013b). Conscious that in 2011, $85 \%$ of global fish production was intended for human consumption (FAO, 2012), one can assume that the former species are the ones more frequently consumed by human population. Likewise, in 2010, $71 \%$ of the exported seafood products were also for food uses (FAO, 2007) and the world's most traded species in value were shrimp (15\%), followed by trout (14\%), salmon (14\%), groundfish (9\%), and tuna (8\%) (FAO, 2011). Indeed, a sizeable share of the fish consumed in developed countries is not due to their own production but from imports, being expected an increasing tendency in coming years, mostly owing to steady demand and declining of domestic fishery catch (FAO, 2012). Surprisingly, most maritime countries are expected to face a significant growth of their aquaculture production (FAO, 2007), and therefore of seafood consumption and exportation. In fact, per capita consumption, representing the total apparent consumption divided by the number of inhabitants of a specific country (FAO, 2007), increased from an average of $9.0 \mathrm{~kg}$ in 1961 to $18.5 \mathrm{~kg}$ in 2009 , incrementing $0.5 \%$ per year regarding global consumption (FAOSTAT, 2014). In particular, concerning world's rank of countries with greater annual per capita consumption, in 2009, Maldives ranked first with $139 \mathrm{~kg} / \mathrm{capita} / \mathrm{year}$, followed by Iceland (88 kg/capita/year), and Kiribati (72 kg/capita/year) (FAOSTAT, 2014). Portugal is the main consumer of seafood in the whole EU, counting with $61 \mathrm{~kg} / \mathrm{capita} / \mathrm{year}$, still in 2009, followed by Norway (51 kg/capita/year), Spain (43 kg/capita/year) and Lithuania (41 kg/capita/year) (FAOSTAT, 2014). Aware of the high consumption pattern of such food products, it is thus pertinent to emphasize their actual contribution to human exposure to BFRs prior to balance the risks and benefits of seafood consumption. 


\section{BROMINATED FLAME RETARDANTS: FROM CAUSE TO EFFECT}

Current knowledge assumes that non-occupational human exposure to the most prevailing BFRs relies mainly on a combination of exposure through diet and ingestion/inhalation of indoor dust and air at home, in cars or at work environments (Asante et al., 2013). However, the accurate input of these pathways varies substantially between contaminants, exposed individuals and populations. Nowadays, there is a reasonable number of studies regarding human exposure to established BFRs (as PBDEs, PBBs or TBBPA), but only a few are available about the "novel" BFRs, i.e. those which are new to the market or just recently observed in the environment (as HBB, DBDPE and BTBPE), (Covaci et al., 2011). Nevertheless, due to their physicochemical resemblances to the formers (Table 1), similar routes of human exposure can be expected (Covaci et al., 2011).

The following subsections will briefly point out the major physicochemical properties of such BFRs and some novel ones, as well as few studies on their assessment in abiotic matrices and toxicity, focusing thereafter on seafood contamination, the main purpose of the current review. Each section will be complemented by a table summarizing most studies published from 2004 to 2014 regarding seafood contamination with these BFRs (Tables S1 to S7). The amounts of contaminants referred in each table include the highest and the lowest quantified values reported (HQV and LQV, respectively), either for individual congeners when detailed, or for "Total" BFRs, comprising the sum of congeners identified in the corresponding study. Only research articles regarding nonexperimentally induced contamination in seafood were included, except the papers where control group values were reported. Figure 1 gathers the published scientific papers regarding seafood contamination by established and novel BFRs, from 2004 to 2013. The keywords used for this research were: "polybrominated diphenyl ether", "PBDE", "polybrominated biphenyl", "PBB", "hexabromocyclododecane”, "HBCDD”, “hexabromobenzene”, "HBB”, “tetrabromobisphenol-A", "TBBPA", "decabromodiphenyl ethane", "DBDPE", "1,2-Bis(2,4,6-tribromophenoxy)ethane", "BTBPE", "fish", and "seafood". As observed in Figure 1, the number of research articles under these conditions has been increasing annually, particularly for PBDEs and HBCDDs. However, only few articles on novel BFRs have been published. 


\section{Polybrominated diphenyl ethers}

\section{Physicochemical characterization}

PBDEs constitute a class of brominated neutral aromatic compounds with a basic structure consisting of two phenyl rings linked by an ether bond (Table 1). The PBDEs family embraces 209 congeners, with molecular weights varying from 249 (BDE-1, BDE-2 and BDE-3) to 959 (BDE-209) (EFSA, 2011b). PBDEs exist in twist or skew conformations, and the higher the degree of bromination, the more skewed is the conformation (EFSA, 2011b).

PBDEs are also highly lipophilic substances, whose $\log \mathrm{K}_{\mathrm{ow}}$ may achieve 8.82 in BDE-209 (Braekevelt et al., 2003). Furthermore, such compounds are non-ionisable and present low volatility, since its vapour pressure may reach $2.17 \times 10^{-13} \mathrm{kPa}$ at $25^{\circ} \mathrm{C}$ in BDE-209 (EFSA, 2011b).

PBDEs chemical stability is strongly influenced by their individual structure. In particular, congeners with four to eight bromine substituents are more stable, while highly brominated PBDEs may experience photolysis and reductive debromination, although being less vulnerable to nucleophilic aromatic substitution (except BDE-209) and oxidations (EFSA, 2011b).

\section{Sources and environmental fate}

PBDEs are additive flame retardants often applied in plastics, textiles, electronic castings and circuitry. These technical PBDEs products are manufactured after bromination of diphenyl ether in the presence of a Friedel-Craft catalyst in a solvent (EFSA, 2011b). The major technical products contain mainly Penta-BDEs, Octa-BDEs or Deca-BDE, but they also contain other PBDEs congeners (EFSA, 2011b). In general, Penta-BDEs are commonly applied in printed circuit boards, cable sheets, furniture, and textiles (Kefeni et al., 2011). On the other hand, Octa-BDEs are usually applied in television sets, computer housings, business machines, household appliances, and other small electronics devices (Kefeni et al., 2011). Finally, Deca-BDE is used for all the aforementioned purposes as in the transportation, construction, and building sectors (Kefeni et al., 2011). However, concerning the above mentioned congeners, only Deca-BDE, which comprises mainly BDE-209, keeps to be produced. Due to its instability and simple debromination (photodegradation, anaerobic biodegradation), it is not considered a persistent BFR, despite its possible conversion to Tetra- and 
Nona-BDE (Xu et al., 2013). Generally, it is believed that its large molecular size, low vapour pressure (subcooled vapour pressure $=5.01 \times 10^{-12} \mathrm{kPa}$; Wania and Dugani, 2003) and high hydrophobicity $\left(\log \mathrm{K}_{\mathrm{ow}}=8.7\right.$; Wania and Dugani, 2003) results in limited capacity for long-range atmospheric transport (Wania and Dugani, 2003) and low bioavailability (Hardy, 2002).

Owing to their widespread use in the last decades, PBDEs are ubiquitously present in the environment and, likewise in biota and in feed and food. Hydroxylated-PBDEs (OH-PBDEs), with one to three hydroxyl groups, appear to result primarily from biotransformation on living organisms (Wiseman et al., 2011; Wang et al., 2014). Similarly, it has also been shown that several organisms can produce methoxylated PBDEs (MeO-PBDEs) (Teuten et al., 2005; Löfstrand, et al., 2011; Rotander et al., 2012; Wang et al., 2012; Wang et al., 2014).

PBDEs can find their way into the environment by several different routes and processes. For instance, numerous studies have reported distinct amounts in air and indoor dust from home or office environments, day care centres, electronics recycling facilities, among others, mainly with Pentaand Deca-BDE (Fromme et al., 2009; Vorkamp et al., 2011; Wit et al., 2012; Tue et al., 2013; Watkins et al., 2013; Kakimoto et al., 2014). There are also few reports concerning the uptake of PBDEs by plants (Vrkoslavová et al., 2010; Wang et al., 2014).

\section{Seafood occurrence}

Dietary route, in particular through seafood consumption, is a main contributor to human exposure. Table S1 summarizes published studies from 2004 to 2014 regarding seafood contamination with PBDEs, with a total of 226 original research articles. In general, and based on the number of published articles, Chinese (Guo et al., 2008; Hu et al., 2010; Ma et al., 2013; Huang et al., 2014) and Spanish research teams (Eljarrat et al., 2004; Martí-Cid et al., 2007; Blanco et al., 2011; Parera et al., 2013), as well as those from Nordic countries (Burreau et al., 2006; Koistinen et al., 2008; Frantzen et al., 2011; Berg et al., 2013) are the ones with greater interest and advances in this particular class of POPs. As expected, the PBDEs congeners more frequently analysed and present in greater amounts in seafood, regardless of the selected analytical methodology, are \#47, 99, 100, 153, 154, 183 and 209, all included in the list of those already under regulation (ECR, 2009; ECD, 2009). 
In particular, BDE-47 is commonly the most concentrated pollutant in seafood, reaching up to 81800 ng. $\mathrm{g}^{-1}$ lipid weight (LW) in mud carp as reported by Wu et al. (2009). This might be related to the bioaccumulation ability of BDE-47 as well as due to wrong waste disposal approaches or its presence in recycled products kept in the market.

Research dedicated to the assessment of PBDEs in seafood started many years before their methoxylated and hydroxylated derivatives (Teuten et al., 2005; Löfstrand, et al., 2011; Wiseman et al., 2011; Rotander et al., 2012; Wang et al., 2012). This might be a result of the unawareness of their existence, later availability of standards or even the development of more sensitive and effective extraction and analytical techniques. Besides, early studies on this matter reported BFR amounts as "ng.g ${ }^{-1 ،}$, further evolving to " $\mathrm{pg} . \mathrm{g}^{-11}$, corroborating improved analytical sensitivity.

Concerning the most studied tissues, fish muscle is by far of greater nutritional and analytical interest, followed by whole soft tissues, whole body tissue and liver. Knowing that these pollutants have, in general, of high lipophilic character, it is clearly observed that lower amounts of BFRs are present in muscle rather than in hepatic tissues, especially if results are expressed on a wet weight basis. Therefore, samples of higher fat content will undoubtedly reveal higher degrees of contamination, thus special attention must be paid to their assessment, including also fish oil samples. Besides, according to works cited in Table S1, carp species are those more frequently studied, followed by mussel, crab, eel, salmon, bass, trout, bream, croaker and shrimp. It is also interesting to state that the highest levels of total PBDEs were detected in benthic or benthopelagic

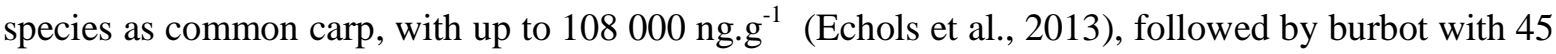
144 ng.g ${ }^{-1}$ (Mariussen et al., 2008), 32900 ng.g g $^{-1}$ (Berg et al., 2013), and 6923.0 ng.g ( $^{-1}$ (LW) (Olsvik et al., 2013), and Chinese loach with 16963.39 ng.g $^{-1}$ (Qin et al., 2009), all expressed on a LW basis. This observation might be related to a more direct exposure to contaminated waste, located in sea or river bottom, where these species preferentially dwell and feed. It would be fundamental to carry on more studies to ascertain if benthic species are, in fact, more vulnerable to BFRs pollution.

On the whole, seafood samples analysed in reported studies came mostly from marine environments, followed by rivers, lakes or aquaculture (Table S1). Conscious that aquaculture will keep growing for the next years ahead, few studies focused on the assessment of BFRs in aquaculture seafood and 
feed, despite the reduced amounts described in published works (Carro et al., 2005; Rodil et al., 2005; Montory and Barra, 2006; Bayen et al., 2007; Rodil et al., 2007; Shaw et al., 2008; NácherMestre et al., 2010; Olli et al., 2010; Blanco et al., 2011; Yu et al., 2011b; Crouse et al., 2013).

However, there is also a lack of studies pointing to the evaluation of food processing conditions on BFRs amounts in seafood, aiming potential human exposure assessment. For example, as detailed in Table S1, only few studies were dedicated to the analysis of processed seafood (Schecter et al., 2010; Shanmuganathan et al., 2011; Törnkvist et al., 2011; Roszko et al., 2013), though, none of them explored the former issues.

\section{Toxicity studies}

As mentioned previously, commercial PBDEs technical products predominantly comprise mainly Penta-, Octa- and Deca-BDE products. In 2001, a full description on hazard identification and doseresponse assessment of PBDEs in fish and aquatic invertebrates was performed, revealing changes in their hepatic morphology $(\mathrm{ECB}, 2001)$. More recent studies verified dose responsive mitochondrial oxidative phosphorylation and apoptotic transcripts, and induction of vitellogenin and CYP1A mRNA expression in both European flounder and Atlantic salmon, thus affecting key biological pathways as xenobiotic biotransformation, regulation of proliferation, endocrine metabolism and glucose homeostasis (Søfteland et al., 2011; Williams et al., 2013).

In addition, seafood neurobehavioral performance was also proved to be affected by PBDEs exposure. For instance, zebrafish (Danio rerio) embryos exposed to BDE-47 showed changes in motor development and swimming behavior in response to light-to-dark photoperiod stimulation, at different growth stages (Chen et al., 2012a). More specifically, zebrafish exposed to a PBDE technical mixture, DE-71, had significantly increased acetylcholinesterase activity, and showed downregulation of mRNA expressions of several marker genes related to central nervous system development (Chen et al., 2012b). Reproductive effects have also been observed in several species, such as mature sperm reduction, decrease of hatching rate, and reduced larval survival (Muirhead et al., 2006; Kuiper et al., 2008; Lee et al., 2012). 
Recent evidence in humans recalls on developmental and endocrine effects of PBDEs as well (Eskenazi et al., 2013; Johnson et al., 2013; Kim et al., 2013; Huang et al., 2014; Toft et al., 2014), yet such findings are not always coherent, most likely due to the focus on different congeners.

\section{Legislation}

Canada is known for their strict policies regarding environmental contaminants. Therefore, the SOR/2008-218 Regulations aim to protect Canada's environment from the risks associated with tetrato deca-BDEs [specified on the List of Toxic Substances in Schedule 1 to the Canadian Environmental Protection Act] (CEPA, 1999; CR, 2008) by preventing their manufacture and restricting their use in Canada, thereby minimizing their release into the environment.

Regarding United States of America, several states have banned commercial penta- and octa-BDEs, plus in 2006, the United States Environmental Protection Agency issued a significant new use rule (74 FR 34015, June 13, 2006) demanding a least of 90 days in advance notification from those who intend to manufacture or import any of the PBDEs congeners derived from commercial penta- and octa-BDEs (SNUR, 2006). Furthermore, in 2009, Environmental Protection Agency employed measures to stop production and import of deca-BDE for most uses by the end of 2012, and to cease production and import entirely by the end of 2013 (SNUR, 2012).

As defined in the European Commission Decision 2005/717/EC, Deca-BDE can no longer be used in electronics and electrical applications from July 2008 in Europe, but a maximum concentration value of $0.1 \%$ of total PBDEs by mass in homogeneous materials shall be tolerated (ECD, 2009). In 2009, the Commission Regulation $N^{\circ}$ 552/2009 updated the restriction conditions for Penta-BDE and OctaBDE, set in ANNEX XVII of this Regulation (ECR, 2009). As a consequence, these cannot be placed on the market or used as substances, in mixtures or in articles, at concentrations higher than $0.1 \%$ by mass. Moreover, no goods can be placed on the market if they, or flame-retarded parts, contain amounts higher than $0.1 \%$ by mass of the former substances (ECR, 2009). Nevertheless, since 2010, all PBDEs from tetra- to hepta-BDEs are regulated by the global Stockholm Convention, and scheduled for elimination (SCPOP, 2006). 


\section{Summary}

PBDEs are an important class of additive BFRs that have been massively produced and used in diverse ordinary products for many years. Despite being known as significant contaminants in air and dust samples, dietary intake has been recognized as the major exposure pathway for humans (Fernandes et al., 2008). The most prevalent congener in seafood is BDE-47, being its hydroxylated and methoxylated derivatives the most frequently detected among PBDEs metabolites. As regards to its toxicity, endocrine and developmental effects are often described in fish and humans, after their exposure to these pollutants. While many PBDEs are strictly regulated for commercialized mixtures and articles, there is no legislation concerning their presence in seafood products. In order to be correctly implemented and to assure accurate reports, it is imperative to implement interlaboratory tests for the establishment of official analytical methods enabling the setting of reference laboratories as well as the development of certified reference materials.

\section{Polybrominated biphenyls}

\section{Physicochemical characterization}

PBBs are also a class of neutral brominated aromatic hydrocarbons, with a basic structure consisting of two phenyl rings to which the bromine atoms are attached (Table 1), but without the ether-bond characterizing the PBDEs. The number and position of the bromine atoms define the PBB congener, also among 209 possible compounds. Depending onon the planar or non-planar configuration, different interactions with biological receptors may be achieved, determining their toxicological properties (EFSA, 2010).

The PBBs congeners have molecular weights ranging from 233 to 943, depending on the number of bromine substitutions (EFSA, 2010). Furthermore, with the increasing degree of bromination, PBBs become more lipophilic, thus achieving lower vapour pressures and water solubility. BB-209 is the congener with higher bromine substitution, whose $\log \mathrm{K}_{\mathrm{ow}}$ is the highest (9.4) and vapour pressure is the lowest $\left(3.23 \times 10^{-13} \mathrm{kPa}\right.$ at $\left.25^{\circ} \mathrm{C}\right)(\mathrm{EFSA}, 2010)$. The degree of bromination also defines their chemical stability, though in general, they are highly chemically stable showing resistance to acids, 
bases, heat and oxidation (EFSA, 2010). Recke and Vetter (2007) evaluated the photochemical debromination of BB-209 by UV light, sun simulator, and natural sunlight, and concluded that all techniques led to reductive debromination, even if at different speeds.

\section{Sources and environmental fate}

PBBs are established flame retardant additives, produced until the mid-1980s, except for Deca-BB which was manufactured until around 2000. Globally, Hexa-, Octa-, and Deca-BB have been produced on a limited number of congeners (Hardy, 2002). They were frequently applied in synthetic fibers and polymers, in particular to a thermoplastic (acrylonitrile-butadiene-styrene) used in housings for office equipment (Hardy, 2002). However, they were not chemically bound to the polymer matrix, thus being easily leached into the environment (ATSDR, 2004; EFSA, 2010). The PBBs environmental impact will be recalled due to Michigan's episode in 1973, when huge amounts of Hexa-BB product were accidentally included in livestock feed, leading to a massive loss of farm animals and derived products (Hardy, 2002).

Major environmental sources of BFRs comprise air and dust contamination as well as the e-waste recycling process, hence, PBBs are not an exception. Together with other BFRs, BB-209 was found in elevated amounts at e-waste storage facilities in Thailand, particularly in a rooms where discarded personal computers and printers were stored (Muenhor et al., 2010). In Northern China, human exposure to these organic pollutants from an e-waste dismantling site was estimated, showing how occupational workers are highly prone to contamination (Yang et al., 2013). Wang et al. (2009a) estimated PBBs congeners (BB-1, -3, -9, -15, -30, -77, -103, -169, -209) in soil samples from three different e-waste disposal facilities namely rude boilers, acid baths and direct end-up dumps, with total PBBs higher at the latter location. As for other BFRs, soil contamination with PBBs may generally be a consequence of municipal sludge disposal to landfills.

Based on the reported data on occurrence in food, special attention is paid to PBBs congeners: BB-3, $-15,-29,-49,-52,-77,-80,-101,-103,-126,-153$ (Hexa-BB), -169 (Hexa-BB), -180, -194 (OctaBB), -206 and -209 (Deca-BB) (EFSA, 2010). 


\section{Seafood occurrence}

In accordance with the PBBs disuse in flame retardant mixtures for more than one decade, only 12 original research articles regarding seafood contamination with these pollutants have been published since 2004, as listed in Table S2. However, these pollutants are still detected in seafood samples (Table S2), with BB-153 being the most often analysed congener as well as the one reaching highest figures (Zhu and Hites, 2004; Evenset et al., 2005; Zhou et al., 2010; Munschy et al., 2011).

In general, PBBs are present in seafood in low amounts, even with the improvement of more sensitive analytical equipment as gas chromatography with high resolution mass detection, which is currently used to assess PBBs in this matrix (McHugh et al., 2010; Wan et al., 2010; Munschy et al., 2011). As for PBDEs, fish muscle tissue is the most analysed fraction, being trout the most studied species (Table S2). The continuous assessment of these substances should not be discontinued because not all PBBs are under regulation or in total disuse, plus bioaccumulation and toxicological effects demand its careful monitoring.

\section{Toxicity studies}

Toxicological studies on PBBs date back decades ago, reflecting the phase-out of the manufacture and use of these contaminants, still few research works on the field will be highlighted. Generally, most of the reported studies have been performed with Hexa-BB mixtures. Technical PBBs mixture (Firemaster FF1) and BB-153 were administered to sheepshead fish (Archosargus probatocephalus), the former causing induction of hepatic microsomal enzymes activity, being this phenomenon highly evidenced on winter season (James and Little, 1981). The possible risk of BB-153 to fish early life stage survival was determined in rainbow trout by Hornung et al. (1996). The authors observed several signs of toxicity, such as yolk sac edema, pericardial edema, multifocal haemorrhages, reduced growth, and craniofacial malformation. The authors also verified a decreased potency with increased bromine substitution, plus BB-153 was 10-fold more potent than identically substituted PCBs. More recently, reproductive toxicity tests were performed to assess the effects of congener153 of PBBs, PBDEs and PCBs, on Daphnia magna, revealing that the amount of BB-153 that accumulated into the Daphnia was half of that of CB-153 but caused the same reduction in the 
offspring production, though CB-153 proved to be the most toxic and BDE-153 the least (Nakari and Huhtala, 2008).

\section{Legislation}

Rotterdam Convention, signed in September 10, 1998, entered into force on February 24, 2004 and embraces 154 worldwide parties presently. It consists on a multilateral treaty to promote shared responsibilities and cooperative efforts on importation of hazardous chemicals, as hexa-, octa- and deca-BB (RC, 1998). As for PBDEs, PBBs appear on the List of Toxic Substances (Schedule 1) of the Canadian Environmental Protection Act, 1999 (CEPA, 1999), and were regulated under the Polybrominated Biphenyls Regulations, 1989.

According to the Directive 2002/95/EC of the European Parliament and of the Council of 27 January 2003, new electrical and electronic equipment put on the market after 1 July 2006 shall not contain PBBs (ECD, 2003), though a maximum concentration value of $0.1 \%$ by weight in homogeneous materials shall be tolerated (ECD, 2003).

With effect from 9 October 2012, Regulation $N^{o}$ 1907/2006 defines the conditions of PBBs restrictions. However, only Hexa-BB congeners (CAS No 59536-65-1) are detailed in ANNEX XVII to this Regulation (ECR, 2006b). It states that it shall not be used in textile articles, such as garments, undergarments and linen, intended to come into contact with the skin. Furthermore, if the articles does not comply the former conditions, they shall not be placed on the market.

In 2010, during the Conference of the Parties of the Stockholm Convention, amendments to the Annexes A of this convention were adopted, and consequently Hexa-BB was classified as a POP of strict elimination (SCPOP, 2012).

\section{Summary}

PBBs constitute a group of additive BFRs that, despite not being currently manufactured, are still present in both biotic and abiotic samples, due to their environmental persistence. Only few studies in the past decade focused their assessment in seafood, most likely owing to the fact that they are not commercially relevant nowadays. Regardless of their known toxicity, they are not regulated in 
seafood. The amounts found on the few reported studies demonstrate that the contaminations levels are relatively smaller than other BFRs, being thus probably more interesting to focus the research on those BFRs whose amounts are definitively larger in the present days.

\section{Hexabromocyclododecanes}

\section{Physicochemical characterization}

HBCDDs are established BFRs formed via addition of bromine to 1,5,9-cyclododecatriene, consisting mainly in three stereoisomers $(\alpha-, \beta$ - and $\gamma$-HBCDD) with six bromine atoms each (Table 1) (EFSA, 2011d). The presence of small amounts of two minor diastereomers, $\delta$ - and $\varepsilon$-HBCDD, has been reported by Arsenault et al. (2007). They are non-ionisable compounds and do not absorb ultraviolet light above $290 \mathrm{~nm}$ (EFSA, 2011d).

The most abundant isomer is $\gamma$-HBCDD, but $\alpha$-HBCDD is the most persistent, derived from its physicochemical and reactivity features. Additionally, experimental studies have shown that $\gamma$ HBCDD is efficiently rearranged to $\alpha-\mathrm{HBCDD}$ at high temperatures (Peled et al., 1995; Alaee et al., 2003).

\section{Sources and environmental fate}

Technical HBCDDs is a mixture of the three main isomers mentioned (approximately $10 \% \alpha, 10 \% \beta$ and $80 \% \gamma$ ), frequently used in polystyrene foam insulation, mainly in building and construction industry, and in polymer dispersion as textile back-coating on cotton or cotton mixed with synthetic blends (EFSA, 2011d), (Alaee et al., 2003; Heeb et al. 2008). For this applicability, HBCDDs particles need to be very small, and thus they are micronized (EFSA, 2011d). HBCDDs may also be used in high impact polystyrene for electrical and electronic equipment and appliances, though this is a minor application (EFSA, 2011d).

Total HBCDDs can be found as widespread contaminants in the environment. All HBCDDs isomers were found in dust from car cabins and trunks, being the mean concentrations higher for $\gamma$-HBCDD, as expected, though $\alpha$-HBCDD was significantly more prevalent in cabin dust than in trunk dust (Harrad and Abdallah, 2011). Ni and Zeng (2013) state that, depending on the surrounding 
environment, HBCDDs exposure via indoor dust inhalation and ingestion might contribute more than dietary pathway.

Furthermore, wet deposition of BFRs in the Great Lakes basin was assessed by Robson et al. (2013) revealing that HBCDDs were major contaminants, with average concentrations of $2.0 \mathrm{ng} / \mathrm{L}$, but reaching up to $60 \mathrm{ng} / \mathrm{L}$.

HBCDDs fate and uptake by plants (cabbage and radish) was investigated by Li et al. (2011). Bioaccumulation was effective and interesting, once $\alpha$-HBCDD was predominantly found in shoot tissues for both species (Li et al., 2011). The increased HBCDDs concentrations observed when cabbage and radish were planted together suggested that interactions between plant species might enhance the bioavailability of HBCDDs (Li et al., 2011). In parallel, Wu et al. (2012) evaluated the HBCDDs diastereoisomers uptake, translocation, and toxicity to maize, revealing the generation of reactive oxygen species and consequent DNA damage.

Tomko and McDonald (2013) evaluated recently the potential emission of HBCDDs into the environment, indicating that up to $500 \mathrm{~kg} / \mathrm{year}$ may be released from a landfill and recycling facilities such as the one they assessed in Canada. The studied model indicated that the three main HBCDDs isomers partitioned similarly into environmental media, and since they have shown bioaccumulation features, they may affect agricultural food crops and the park ecosystem

\section{Seafood occurrence}

A total of 79 original research articles regarding seafood contamination with HBCDDs since 2004 are listed in Table S3, which numbers increase as the years pass. HBCDDs results are either expressed as individual congeners or as total amounts, depending on the authors. However, $\alpha$ HBCDD is the most concentrated congener in seafood reaching elevated amounts as those reported by Chen et al. (2011) and Köppen et al. (2010) (Table S3) of up to 11140 ng. ${ }^{-1}$ LW.. Nevertheless, $\gamma$-HBCDD was predominant in some samples, reaching up to $267 \mathrm{ng} \cdot \mathrm{g}^{-1} \mathrm{LW}$, in sharks (JohnsonRestrepo et al., 2008). Furthermore, Harrad et al. (2009) quantified, for the first time, the $\delta$-HBCDD isomer in all studied samples (Table S3). 
Until 2006, HBCDDs were commonly analysed by gas chromatography (Table S3), when it was verified that these compounds are thermo labile and therefore not adequate for gas chromatography techniques (Alaee et al., 2003). Therefore, liquid chromatography coupled to mass spectrometry detection, mostly with electrospray ionization, started to be employed for their assessment. Additionally, few studies are already using ultra-pressure liquid chromatography equipment and multi-dimensional mass spectrometry, achieving faster and more sensitive outcomes.

Most studies were performed in China (Xian et al., 2008; Meng et al., 2012; He et al., 2013) and Norway (Mariussen et al., 2008; Haukas et al., 2010; Berg et al., 2013), predominantly comprising marine seafood. Fish muscle tissue is once more the most studied sample type, followed by whole soft tissues and whole body tissue (Table S3). There is a huge diversity of seafood species analysed, with a special focus on carp, mackerel, eel and cod. Herein, highest figures of total HBCDDs were again detected in benthic or benthopelagic species: cod with 30320 ng.g ${ }^{-1}$, DW (Köppen et al., 2010), oyster with $5200 \mathrm{ng} \cdot \mathrm{g}^{-1}$, LW (Ueno et al., 2010), yellow eel with $9500 \mathrm{ng} \cdot \mathrm{g}^{-1}$, LW (Malarvannan et al., 2014), and burbot with 3380 ng.g $^{-1}$, LW (Berg et al., 2013).

The temporal trends observed by Chen et al. (2011) suggest that the use of HBCDDs may have risen. In particular, carp samples from Hyco River evolved from 13 ng. ${ }^{-1}, \mathrm{LW}$, in 1999-2002, to 4640 ng.g ${ }^{-1}, \mathrm{LW}$, in 2006-2007, of total HBCDDs Chen et al. (2011). Hence, there is an urgent need for HBCDDs to be included in ongoing monitoring action plans, in order to ease assessment of its use, release, and environmental impacts.

\section{Toxicity studies}

According to Deng et al. (2009), HBCDDs are able to produce developmental toxicity in zebrafish embryos, likely due to the generation of reactive oxygen species and the consequent triggering of apoptosis genes. These same outcomes were verified by Du et al. (2012), but these authors were also able to conclude that HBCDDs can act in a dose-dependent and diastereoselective manner $(\gamma$ HBCDD $>\beta$-HBCDD $>\alpha$-HBCDD). Hepatic oxidative stress has also been observed in goldfish (Carassius auratus) after prolonged exposure to several BFRs, being HBCDDs some of the most 
biotoxic chemicals, probably due to its slow metabolism and potential to bioaccumulate (Feng et al., 2013a).

Early life developmental effects on sea urchin (Psammechinus miliaris) exposure to several POPs were conducted by Anselmo et al. (2011). The authors observed that developing larvae were particularly sensitive to HBCDDs exposure, with a no-observed-adverse-effect-concentration of 25 $\mathrm{mM}$ and $50 \mathrm{nM}$ for larval development and morphological abnormalities, respectively.

Low-level HBCDDs exposure of zebrafish embryos resulted in an increase in heart rate and cardiac arrhythmia after exposure for $72 \mathrm{~h}$, through to the upregulation of mRNA expression of $R y R 2$ and Atp $2 a 2 b$ genes, associated to calcium ion transport of cardiomyocytes (Wu et al., 2013).

\section{Legislation}

HBCDDs have been listed since 1998 among the "chemicals suspected of having endocrine disrupting effects" by the World Wildlife Fund and the Japanese Environment Agency (NIES, 1998). Based on the results of the draft screening level risk assessment for HBCDDs, the USA government concluded that HBCDDs met the criteria outlined in section 64 of CEPA, 1999. Besides, in 2013, Environmental Protection Agency conducted a risk assessment on HBCDD pursuant to the 2010 "Toxic Substances Control Act" action plan, that describes possible actions including conducting a risk assessment (EPA, 2013a). In Europe, all three main HBCDDs isomers identified are currently included in the list of substances subjected to authorization (ECR, 2006b). Furthermore, in 2013 the POPRC of the Stockholm Convention received approval for inclusion of HBCDDs in Annex A of the Convention, with a specific exemption for production and use in expanded polystyrene and extruded polystyrene in buildings (UN, 2013).

\section{Summary}

HBCDDs are additive BFRsused for many years and can be effective alternatives for PBDEs in some applications. However, they are presently detected in a wide variety of environmental samples, being the second most studied BFR in seafood (Figure 1). In comparison to PBDEs and PBBs, the toxicological knowledge on HBCDDs is still restricted, though hepatic, neurological and 
cardiovascular events have been described in seafood. Despite not being legislated for seafood, HBCDDs application is receiving more attention from regulatory authorities, being currently under the Stockholm Convention control.

\section{Tetrabromobisphenol A and other brominated phenols}

\section{Physicochemical characterization}

The basic structure of TBBPA, an emerging BFR produced by bromination of bisphenol A, consists of two hydroxyphenyl rings linked by a carbon bridge, with bromine substitution at the $3,3^{\prime}, 5$ and 5'-positions (Table 1). Brominated phenols present slightly acidic properties, with pKa values between 4 and 8 . Thus, once TBBPA has two phenol groups, it presents two pKa values (7.5 and 8.5) (EFSA, 2012).

TBBPA is characterized by a high lipid solubility ( $\log \mathrm{K}_{\text {ow }}$ of 9.7 , corresponding to the protonated compound; experimental $\log \mathrm{K}_{\mathrm{ow}}$ show lower values, from 3.2 to 6.4 at neutral $\mathrm{pH}$ ), and low volatility (Table 1) (EFSA, 2011c). Moreover, TBBPA is not hydrolysed and is not subjected to substitution reactions in the environment, but it is easily polymerized or co-polymerized due to the reactivity of its phenol groups (EFSA, 2011c).

TBBPA suffers photo transformation under UV irradiation at various pHs, generating three major isopropyl-phenol derivatives: 4-isopropyl-2,6-dibromophenol, 4-isopropylene-2,6-dibromophenol and 4-(2-hydroxyisopropyl)-2,6-dibromophenol (Eriksson et al., 2004). Zhong et al. (2012) evaluated the effect of organic solvents on these transformations during solvent-based processing of e-waste. Results showed that toluene and methanol had no effect on TBBPA, but approximately $20 \%$ of TBBPA was transformed by acetone within $2 \mathrm{~h}$ at $50{ }^{\circ} \mathrm{C}$. In addition, the presence of co-existing metals in the e-waste, such as $\mathrm{Zn}, \mathrm{Cu}$, and $\mathrm{Ni}$, greatly enhanced TBBPA transformation rates.

There are several TBBPA derivatives, though those which might be used as BFRs are: Tetrabromobisphenol A bismethyl ether and Tetrabromobisphenol A bispropanoate (EFSA, 2011c). Similarly, other brominated phenols are technically produced by phenol bromination to contain 2,3 or 5 bromine substituents (EFSA 2012b). The structural formulas of 2,4-dibromophenol (2,4-DBP) and 2,4,6-tribromophenol (2,4,6-TBP) are presented in Table 1. In comparison to other BFRs, 2,4- 
DBP and 2,4,6-TBP are less lipophilic and more volatile and acidic due to the presence of the phenol groups (Table 1) (EFSA, 2012).

\section{Sources and environmental fate}

Presently, TBBPA is known to be the highest-volume BFR produced worldwide, representing about $60 \%$ of the total BFR market. It is used as a reactive BFR mostly in polymers and electronics (laminate for printed circuit boards). Furthermore, TBBPA is also used as an additive flame retardant in the manufacture of acrylonitrile butadiene styrene resins (a better alternative to Octa-BDE), high impact polystyrene, and phenolic resins (EFSA, 2011c). In general, TBBPA is chemically bound to the polymer matrix of the product into which it is applied, unlike HBCDDs and PBDEs, thus limiting its release to the environment (Morris et al., 2004).

Despite being extensively applied, information regarding TBBPA presence in abiotic and biotic matrices is scarce comparing to aforementioned BFRs. Xie et al. (2007) analysed TBBPA in outdoor air samples from a rural site in northern Germany, over the Wadden Sea and offshore in the Northeast Atlantic Ocean. A declining trend with increasing latitude was observed from the Wadden Sea to the Arctic. However, the occurrence of TBBPA in the Arctic atmosphere was significant and might imply that TBBPA has long-range transport potential (Xie et al., 2007). TBBPA has also been quantified in sewage sludge samples in Spain, along with other BFRs, though in smaller amounts comparing to PBDEs and DPDPE (Gorga et al., 2013). It has also been verified that bryophytes hornwort may uptake TBBPA from water in a dose dependent manner (Sun et al., 2008). Harrad and Abdallah (2011) determined TBBPA presence in dust from the four seats in five different cars, measuring usually higher levels in the front seats. Ni and Zeng (2013) found considerable amounts of TBBPA in air conditioning filter dust, exposing how dust inhalation might constitute a major pathway for human exposure.

As regards to the other main brominated phenols, 2,4-DBP and 2,4,6-TBP, they are used as reactive flame retardant in epoxy resins, phenolic resins, polyester resins, polyolefins and vinyl-aromatic polymers (EFSA, 2012). In addition, 2,4,6-TBP is also used as a fungicide for wood treatment 
(EFSA, 2012). Moreover, 2,4,6-TBP is a common precursor for other BFRs, such as BTBPE (EFSA, 2012)

2,4-DBP and 2,4,6-TBP were found in plenty different matrices, as outdoor and indoor air samples, marine sediments, sewage sludge and moss samples (Nordic Council of Ministers, 2011). Regarding their presence in the latter, it is possible to state that its levels reflect deposition from air rather than uptake from soil or other substrates (EFSA, 2012).

Though 2,4,6-TBP can be formed as a metabolite from certain PBDEs, both 2,4-DBP and 2,4,6-TBP are common marine secondary metabolites (EFSA, 2012). Thus, brominated phenols metabolites can reach crustaceans and fish via ecological food chains (EFSA, 2012). However, their function is not yet clear, but some may play a role in chemical defence and deterrence (EFSA, 2012).

\section{Seafood occurrence}

Table S4 summarizes the published papers from the past decade on the subject of TBBPA determination in seafood. Probably due to the absence of legislation regarding the presence of TBBPA on abiotic or biotic material, there is a lack of studies regarding this matter. In fact, during 10 years of research only 12 scientific works have been developed, despite being TBBPA one of the most common BFRs in industry.

In opposition to other previously discussed BFRs, TBBPA was mostly analysed in river fish samples. However, the edible fraction - fish muscle tissue - keeps being the more desirable matrix type to be studied and almost all papers include carps as sample material. Furthermore, TBBPA is analysed mainly by liquid chromatography with electrospray ionization and mass spectrometry detection, possibly to its low volatility, being usually quantified together with HBCDDs or other halogenated phenols.

In comparison to HBCDDs, Morris et al. (2004) verified that only few samples exhibited TBBPA contamination and, when found, it was present in low amounts. The authors describe it as a result of the more polar and reactive molecular properties of TBBPA, leading to a lower degree of bioaccumulation (Morris et al., 2004). There is also the possibility of TBBPA being bound to other endogenous compounds like proteins, being inefficiently extracted or interfering with extraction 
steps (Morris et al., 2004). Nevertheless, Morris et al. (2004) determined the highest figures of TBBPA in seafood, in particular in whiting muscle and cod liver, among all cited studies (Table S4), with 245 ng. $\mathrm{g}^{-1} \mathrm{LW}$. In Belgium, TBBPA was only determined in trace amounts in mysid from the two most inland sites of Scheldt estuary (Verslycke et al., 2005), probably to the lower dilution factor. In another study, European flounder was experimentally exposed to different TBBPA concentrations for 105 days), reaching levels in muscle samples up to 200 times higher than the

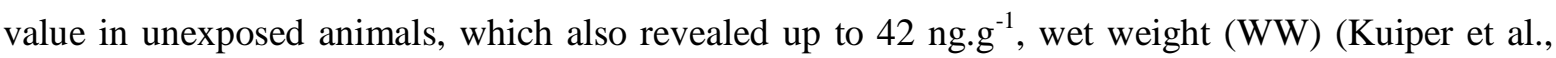
2007).

\section{Toxicity studies}

Early life developmental effects on sea urchin (Psammechinus miliaris) were observed by Anselmo et al. (2011), with a lowest-observable-adverse-effect-concentration of $1.5 \mu \mathrm{M}$. However, in zebrafish embryos, $1.5 \mu \mathrm{M}$ TBBPA exposure resulted in 100\% mortality (McCormick et al., 2010). Besides resulting in edema and haemorrhage, TBBPA specifically caused decreased heart rate, edema of the trunk, and tail malformations.

Liver enzymatic activity upon TBBPA chronic exposure has been evaluated in crucian carp, revealing irreversible damage for concentrations higher than 0.92-1.30 Mm (Yang et al., 2013b). Hepatic oxidative stress was observed in goldfish (Carassius auratus) after prolonged exposure to TBBPA, although in lesser extent than with HBCDDs (Feng et al., 2013a).

Regarding its endocrine disruption in fish, TPPBA has shown low but multiple hormonal activities in mosquitofish (Gambusia affinis) with significant up-regulation of vitellogenin and estrogen receptors mRNAs in the liver and testis, after exposure to $500 \mathrm{nM}$ and $50 \mathrm{nM}$ of TBBPA, respectively (Huang et al., 2013). Furthermore, TBBPA significantly induced thyroid receptor $\alpha$, thyroid stimulating hormone, and transthyretin genes in zebrafish embryo-larvae, proving to be a major toxicant based on their low 96h-LC 50 values (Chan and Chan, 2012).

Finally, based on toxicity data of TBBPA on Chinese freshwater aquatic species, Yang et al. (2012b) settled a criterion maximum concentration of $0.27 \mu \mathrm{M}$ and a criterion continuous concentration of $0.0232 \mu \mathrm{M}$. 


\section{Legislation}

Up to date, none of the previously mentioned brominated phenols (TBBPA, 2,4-DBP and 2,4,6-TBP) are under regulation regarding their use or production, nor even regarding maximum tolerance levels in foodstuffs. TBBPA is classified as a "Persistent Bioaccumulative Toxic" chemical, thus being included in a chemical category which is subject to reporting under Emergency Planning and Community Right-to-Know Act, Section 313, 1986 (EPA, 2013b). Environmental Protection Agency concluded that TBBPA has sufficient data to conduct a future risk assessment, despite not being identified in the 2012 Work Plan (EPA, 2013a).

Nevertheless, TBBPA has been registered in REACH (Commission Regulation N ${ }^{\circ}$ 1907/2006 concerning the Registration, Evaluation, Authorization and Restriction of Chemicals).

\section{Summary}

TBBPA is presently the most commercially relevant additive/reactive BFR. However, despite being detected in many environmental samples, there is a lack of information regarding its levels in seafood, despite of the awareness on its role as an endocrine disruptor. Furthermore, there are no regulatory restrictions on the production of TBBPA or its derivatives, as well as on their presence in seafood or other food products, highlighting for the present need to monitor their levels and clarify its toxicity and, based on the knowledge achieve on older BFRs, take timely measures to avoid similar widespreading.

\section{Hexabromobenzene}

Physicochemical characterization

Briefly, HBB is an emerging BFR and an aromatic perbrominated compound, which may undergo nucleophilic aromatic substitution with strong nucleophiles and reductive debromination under environmental conditions (EFSA, 2011d). The chemical structure of HBB is presented in Table 1, together with other basic physicochemical features. 


\section{Sources and environmental fate}

HBB was extensively used in Japan as an additive flame retardant in paper, woods, textiles, electronic and plastic materials, but nowadays its use has decreased (EFSA, 2011d). Even though it is not reported to be produced in Europe, Gouteux et al. (2006) stated that HBB is also released from oligomeric BFRs, such as FR-1025 (a pentabromobenzyl acrylate oligomer).

Indeed, several and very recent studies have been performed with regards to HBB environmental fate. A study initiated by the Nordic Council of Ministers (2011), detected HBB in 6 out of 12 sediment samples from Denmark, the Faroe Islands, Finland, Norway and Sweden, as well as in 5 out of 15 sewage sludge samples from the Nordic countries, with the highest amounts found in Iceland.

Salamova and Hites (2011) detected HBB in air (vapour and particles) and precipitation samples (rain and melted snow) at five stations belonging to the US Integrated Atmospheric Deposition Network around the Great Lakes, including urban, rural and remote locations. HBB was highly detected in winter time during northerly wind directions, possibly as a result of thermal reaction of highly brominated flame retardants like BDE-209 (Möller et al., 2012). HBB was also found in sewage sludge samples from different wastewater treatment plants in Spain (Gorga et al., 2013).

\section{Seafood occurrence}

Being an emerging BFR, not listed in a EU priority list (as seen under Council Regulation (EEC) $\mathrm{N}^{\circ}$ 793/93) and not even qualified by the EU for its production amounts (ECR, 2006b; ESIS, 2014), it is understandable that the number of published papers on this pollutant is low (Table S5). Nevertheless, the HBB amounts determined by Munschy et al. (2011) in common sole, from 2007 to 2009, were lower than those reported in freshwater fish in China, $2451 \pm 778{\mathrm{ng} . \mathrm{g}^{-1}}^{-1} \mathrm{LW}$, certainly influenced by the fact that these latter samples were collected from an electronic waste recycling site (Wu et al., 2010).

\section{Toxicity studies}


Few data have been found regarding HBB toxicity in seafood, though it has been tested in different species, such as rodents and birds, revealing generally liver and enzyme activity effects (NPCA, 2009). Notwithstanding, concerning fish toxicological studies, goldfish (Carassius auratus) also presented liver oxidative stress when chronically exposed to $\mathrm{HBB}$, which resulted in higher integrated biomarker response than HBCDDs (Feng et al., 2013a).

\section{Legislation}

Until now, HBB is not regulated under any specific regulation for their use or production, nor even regarding maximum tolerance levels in foodstuffs.

Summary

HBBs are among the BFRs with lower knowledge regarding their use, fate, and toxicological effects. Being almost restricted to Japan it is a probable indicator that, in comparison with other BFRs, its widespread is comparatively shorter. Still adequate monitoring on production levels and used should be performed to define if it requires further studies.

\section{Decabromodiphenyl ethane}

\section{Physicochemical characterization}

The chemical structure of DBDPE and its IUPAC designation are shown in Table 1. Due to its polybrominated character, DBDPE presents a high molecular weight, comparing with the previous BFRs, equivalent to the BDE-209. Moreover, it reveals lipid soluble features and a low volatility (Table 1) (EFSA, 2011a).

DBDPE is an emerging BFR, which was proved to be thermally degraded to bromotoluenes, and photolytically debrominated to nona- and octabrominated congeners, but these effects are more pronounced in standard solutions than in real samples (Kierkegaard et al., 2009).

\section{Sources and environmental fate}


DBDPE was introduced in the mid-1980s and became commercially significant as an alternative to BDE-209. Hence, it has identical applications as the latter, i.e. as an additive to different polymeric materials like high-impact polystyrene and in textiles and leather (Kierkegaard et al., 2009). Just as for the former substances, DBDPE can occur in the environment as a result of release during manufacturing and use.

Despite being listed as a low production volume chemical (between 10 and 1000 tons per year) in the European Union, it was the second most used BFR in China, accounting for an estimated domestic production of 12000 tons, according to Shi et al. (2009a). Chen et al. (2009) found that DBDPE was the most commonly found BFR in children's toys, right after BDE-209, detected in 40-90\% of the toys screened.

Environmental data on DPDPE are scarce in comparison with BDE-209, where studies have revealed that long-range transport in the air leads to contamination of distant regions. Due to their physicochemical similarity, this might be true for DPDPE as well. A recent study found higher amounts of DPDPE than BDE-209 in ambient air samples from southern Sweden, though their concentrations did not co-vary, indicating that there are different major sources of the two compounds (Egebäck et al., 2012). Current studies also detected DPDPE in air, precipitation, sediment, soil and sludge samples (Shi et al., 2009a; Salamova and Hites, 2011; Gorga et al., 2013).

\section{Seafood occurrence}

Besides having only 9 published research works regarding DBDPE in seafood since 2004, most of them do not report quantifiable amounts of this pollutant. On the whole, samples are gathered from freshwater sites, mainly rivers and again fish muscle tissue is chosen for analysis, primarily by gas chromatography with electron capture negative ionization mass spectrometry detection (Table S6).

Munschy et al. (2011) evaluated novel BFRs in common sole, being able to detect DBDPE in both muscle and liver tissues, which was mainly present in the latter, due to its higher fat content.

On the other hand, DBDPE was measured in aquatic environment matrices in China, including fish, by He et al. (2012), with amounts comparable to those reported in fish collected close to an e-waste site South China (Wu et al., 2010), in seafood from Iberian rivers (Santín et al., 2013), and almost 2 
orders of magnitude higher than the levels determined by Law et al. back in 2006. Moreover, He et al. (2012) confirmed that DBDPE may be significantly bioaccumulated in the studied species. In China, DBDPE was not detected in fish but was present in variable amounts in birds, which might be a result of different dietary habits or bioaccumulation tendencies that deserve further attention (Shi et al., 2009).

\section{Toxicity studies}

Literature on the evaluation of DBDPE toxicity in seafood is scarce. Nevertheless, DBDPE suppressed hatching success of zebrafish eggs and increased vitellogenin synthesis, a marker of estrogenic effects, inhibited CYP1-dependent monooxygenase activity, and increased the activity of uridine-diphospho-glucuronosyl-transferase in rainbow and brown trout hepatocytes (Nakari and Huhtala, 2010).

Among the toxicants tested in zebrafish by Feng et al. (2013a), DBDPE was the least toxic substance. Potential effects of DBDPE were assessed in five aquatic and sediment species, concluding that it does not present a risk of acute toxicity to both pelagic and benthic organisms (Hardy et al., 2012).

\section{Legislation}

DBDPE was not regulated under any specific regulation for their use or production, nor regarding maximum tolerance levels in foodstuffs.

\section{Summary}

This novel BFR, highly similar to BDE-209, has been increasingly used as its substitute. Despite being detected in environmental and fish samples, recent toxicological studies show that it is among the BFRs with lower toxicity. Therefore, further studied are necessary to sustain these preliminary observations, in order recommend its use in substitution of other BFRs.

\section{1,2-Bis(2,4,6-tribromophenoxy)ethane}




\section{Physicochemical characterization}

Commonly to all BFRs, BTBPE is a lipid-soluble emergent contaminant of low volatility as defined in Table 1, with some structural resemblances to DBDPE. Balabanovich et al. (2003) studied BTBPE thermal degradation. The main primary thermal decomposition products at $340^{\circ} \mathrm{C}$ were $2,4,6$-TBP and vinyl 2,4,6-tribromophenyl ether. However, when a prolonged contact was established with the heating zone, production of hydrogen bromide, ethylene bromide, polybrominated vinyl phenyl ethers, diphenyl ethers, and dibenzodioxins were also perceived (Balabanovich et al., 2003). Furthermore, BTBPE is highly persistent in the environment, although it may undergo reductive and photolytic debromination (EFSA, 2011a).

\section{Sources and environmental fate}

BTBPE is an additive flame retardant that has been produced since the mid-1970s. It is used in replacement for Octa-BDE in polystyrene, thermoplastics and resins, which may led to a possible increase in its production, though it is still classified as a low production volume chemical in the European Union (EFSA, 2011a).

This novel BFR was detected in indoor dust from two Vietnamese e-waste recycling sites and an urban site, where the formers revealed the highest contamination level as expected (Tue et al., 2013). BTBPE has also been found by Salamova and Hites (2011) as well as by Robson et al. (2013) in air and precipitation samples, but in lower amounts than other BFRs. BTBPE was found as well in sediment, soil and sludge samples from the Pearl River delta close to an e-waste facility in China (Shi et al., 2009a). Furthermore, BTBPE was one of the most commonly found BFRs in children toys. In particular, hard polymers usually contain higher concentrations than soft products as foams (Chen et al., 2009).

\section{Seafood occurrence}

Similarly to DBDPE, only few original research articles are available concerning BTBPE in seafood (Table S7). Most of the analysed samples came from marine environments, being fish muscle tissue 
and whole soft tissues the furthermost studied matrix type. BTBPE is preferably determined by gas chromatography with electron capture negative ionization mass detection (Table S7).

Among all species studied by Wu et al. (2010), mud carp had the greatest BTBPE concentrations (518 \pm 277 ng.g ${ }^{-1}$, LW). Munschy et al. (2011) found reduced BTBPE contamination in common sole, and the authors concluded that BTBPE origin was not directly related to high anthropogenic activity in the Seine estuary, since concentrations in such samples were in the same range as those found in samples from the Atlantic.

As verified for DBDPE, BTBPE was found in higher amounts in fish livers than in muscle, but the overall concentrations were much reduced, reflecting their limited usage in recent years in the Pearl River Delta region, China (Shi et al., 2009a).

\section{Toxicity studies}

There is still a lack of reliable information on the subject of BTBPE toxicity. The only study related to toxic effects of BTBPE in fish showed that, despite having a similar half-life to that of some BDE congeners and having the potential to biomagnify in aquatic food webs, it does not constitute a potent thyroid-disrupting BFR (Tomy et al., 2007).

\section{Legislation}

BTBPE is not regulated under any specific regulation for their use or production, nor even regarding maximum tolerance levels in foodstuffs.

\section{Summary}

Despite being used since de 1970s, its production is relatively low. Still, it is one of the more prevalent BFRs in children toys requiring effective knowledge on its toxicological effects, whose information is relatively scarce.

\section{FISH CONSUMPTION: RISKS VERSUS BENEFITS}


Over the past few years, consumers have become more conscious of the health benefits of regular seafood consumption, which provides valuable polyunsaturated fatty acids, high-quality proteins, vitamins, and other essential micronutrients. However, the presence of environmental contaminants as BFRs has raised some concerns about potential associated health risks. As a result, there is an urgent need to adequately balance risks and benefits of seafood consumption.

Seafood composition and its role in health benefits

\section{Marine lipid fraction}

In 2009, seafood contributed worldwide to the ingestion of $1.2 \mathrm{~g}$ of total fat per capita/day (FAOSTAT, 2014) being a unique source of polyunsaturated fatty acids (PUFA), rich in long-chain $\omega 3$ PUFA as eicosapentaenoic acid (EPA, 20:5 $\omega 3$ ) and docosahexaenoic acid (DHA, 22:6 $\omega 3$ ). Numerous health benefits have been attributed to EPA and DHA, mainly related to cardiovascular diseases, central nervous system development, mental health diseases, inflammation and immune functions (Ackman et al., 2000).

\section{Marine protein fraction}

In 2009, seafood protein supply rounded $5.1 \mathrm{~g} /$ capita/day of world's population (FAOSTAT, 2014).

Seafood proteins contain significant amounts of essential amino acids (EAA); particularly lysine, methionine, cysteine, threonine, and tryptophan, revealing interesting EAA scores as well as good ratios of EAA to non-EAA (Adeyeye, 2009; Usydus et al., 2009; Barrento et al., 2010), thus improving the overall protein quality of a diversified diet. Several health attributes have been addressed to seafood protein, as those related to weight management, increasing of insulin sensitivity and prevention of type 2 diabetes, decreasing of serum high sensitive C-reactive proteins, reducing of plasma total cholesterol as well as exhibiting anti-hypertensive effects (Larsen et al., 2011).

\section{Other marine nutrients}

Vitamin content of seafood plays a fundamental role in preserving healthy lifestyle, with vitamins A, $\mathrm{D}$, and $\mathrm{E}$ as the most prevalent ones. For instance, fatty seafood like European eel and salmon, show 
interesting levels of these vitamins, having $887 \mu \mathrm{g} / 100 \mathrm{~g}$ and $16 \mu \mathrm{g} / 100 \mathrm{~g}$ of vitamin $\mathrm{A}$ and $\mathrm{D}$, respectively, in the former, and $4 \mu \mathrm{g} / 100 \mathrm{~g}$ of vitamin $\mathrm{E}$, in the latter species (Nunes et al., 2006), representing, respectively, $110 \%, 300 \%$, and $33 \%$ of the daily recommended doses (ECR, 2011).

Many elements are also of high dietary relevance for humans at multi-target sites, such as chromium, cobalt, copper, iron, lithium, manganese, molybdenum, nickel, selenium, strontium, vanadium and zinc (O'Dell and Sunde, 1997).

Despite of all these nutritional benefits related to seafood consumption, it might simultaneously represent a potential source of pernicious environmental contaminants, particularly those with lipophilic characteristics as the BFRs previously discussed. However, it is known that the nutritional composition of fish species, and particularly its lipid fraction, is affected by numerous factors, including gender, age, water temperature and degree of pollution, feeding and nutritional condition, season, and inevitably fish origin (Bae et al., 2011), but also the cooking method practiced (Nunes et al., 2006), all contributing to literature inconsistencies in lipids as therefore inevitably also on lipophilic contaminants.

Contaminant occurrence isssues and its role in risk analysis

The toxic effects of recognized environmental contaminants such as PCBs, methylmercury, arsenic and organochlorine pesticides, which are found in many seafood species at high concentrations, turn these food products into a potential health risk for the consumers. Hence, few papers took this matter into consideration. Those who did generally conclude that it is wise to choose the most suitable species in terms of nutritional benefits (mainly derived from its PUFAs profile and amounts) and pollutants from diverse sources rather than fish alone, in order to balance benefits and risks of a regular consumption (Costa, 2007; Domingo, 2007; Sioen et al., 2008; Turyk et al., 2012). Nevertheless, limited consumption of certain fish in children, pregnant women and women of childbearing age is advisable (Costa, 2007).

However, as regards to BFRs, there are no admissible limits for their presence in seafood for consumption purposes. Thus, it is still premature to make a statement on the subject of its intake. Notwithstanding, a probabilistic intake assessment of PBDEs and $\omega-3$ fatty acids through fish consumption was conducted, showing that consuming $150 \mathrm{~g}$ of salmon twice a week, recommended 
to achieve nutritional benefits, contributes on average to a low PBDEs intake, contrariwise to herring or cod were pollutant amounts on a lipid basis are higher (Sioen et al., 2008). Furthermore, both benefits and risks are defined by a complexity of variables, such as fish characteristics (age, gender, overall fat content, size, and feed), environmental conditions (temperature, seasonal catch, pollution) or even pollutant-pollutant and nutrient-pollutant interactions (Bae et al., 2011, Turyk et al., 2012), which should be considered in risk assessment studies. Therefore, only after all these gaps are filled, a practical risk-benefit analysis can be provided.

\section{CONCLUSIONS}

A huge amount of published data on BFRs presence in seafood is being reported in recent years for a variety of established and some novel BFRs, assessed by increasingly more sensitive analytical methodologies, as well as regarding several fish species. The present review revealed, however, some research gaps, particularly regarding monitoring issues and human exposure. Studies focusing on monitoring contamination levels in seafood matrices, for established BFRs, and particularly for the novel ones, are still scarce. Furthermore, several factors that contribute to BFRs variability in seafood, as fish gender, catching season, geographical origin, food processing, among others, are often disregarded. Also, despite the offer of numerous analytical methods for BFRs assessment, the development of multi-residue ones, properly validated through standard reference materials (which need to be produced and made openly available) and interlaboratorial studies, is advisable. Finally, it was observed that there is a lack of information on the bioaccessibility/bioavailability of some BFRs. This information is mandatory to support effective risk assessments studies, clarifying their effective toxicity and giving support to future legislation regarding BFRs presence in seafood.

It is thus clear that these pollutants need to be measured in a wider range of seafood species and locations, with adequate sampling designs, to understand intrinsic and extrinsic factors that may cause variability in their contamination levels, and the subsequent human exposure.

\section{ACKNOWLEDGMENTS}


S.C. Cunha and S. Casal acknowledge financial support from the European Union Seventh Framework Programme (FP7/2007-2013) under the ECsafeSEAFOOD project (grant agreement $n^{\circ}$ 311820). R. Cruz thanks REQUIMTE FCT (Fundação para a Ciência e a Tecnologia) and FEDER through the COMPETE program under the projects FCOMP-01-0124-FEDER-008703 (FCT/PTDC/AGR-AAM/102447/2008) and PEst-C/EQB/LA0006/2013.

\section{Notes}

The authors declare no competing financial interest. 


\section{References}

Abdelouahab N, Suvorov A, Pasquier JC, Langlois MF, Praud JP, Takser L. Thyroid disruption by low-dose BDE-47 in prenatally exposed lambs. Neonatology 2009; 96: 120-124.

Ackman RG (2000) Fatty acids in fish and shellfish in: C-K Chow (Ed) Fatty Acids in Foods and Their Health Implications Marcel Dekker AG Basel pp 153-174

Adeyeye EI. Amino acid composition of three species of Nigerian fish: Clarias anguillaris Oreochromis niloticus and Cynoglossus senegalensis. Food Chem 2009; 113: 43-46.

Ael EV, Covaci A, Blust R, Bervoets L. Persistent organic pollutants in the Scheldt estuary: Environmental distribution and bioaccumulation. Environ Int 2012; 48: 17-27.

Alaee M, Arias P, Sjödin A, Bergman A. An overview of commercially used brominated flame retardants their applications their use patterns in different countries/regions and possible modes of release Environ Int 2003; 29: 683-689.

Al-Mousa F, Michelangeli F. The sarcoplasmic-endoplasmic reticulum Ca2+-ATPase (SERCA) is the likely molecular target for the acute toxicity of the brominated flame retardant hexabromocyclododecane (HBCD). Chem-Biol Interact 2013; 207: 1-6.

Ameur WB, Hassine SB, Eljarrat E, Megdiche YE, Trabelsi S, Hammami B, Barceló D, Driss MR. Polybrominated diphenyl ethers and their methoxylated analogs in mullet (Mugil cephalus) and sea bass (Dicentrarchus labrax) from Bizerte Lagoon, Tunisia. Mar Environ Res 2011; 72: 258-264.

Ameur WB, Megdichea YE, Eljarrat E, Hassine SB, Badreddine B, Souad T, Bèchir H, Barceló D, Driss MR. Organochlorine and organobromine compounds in a benthic fish (Solea solea) from Bizerte Lagoon (northern Tunisia): Implications for human exposure. Ecotox Environ Safe 2013; 88: 55-64.

Anderson TD, MacRae JD. Polybrominated diphenyl ethers in fish and wastewater samples from an area of the Penobscot River in Central Maine. Chemosphere 2006; 62: 1153-1160.

Anselmo HMR, Koerting L, Devito S, van den Berg JHJ, Dubbeldam M, Kwadijk C, Murk AJ. Early life developmental effects of marine persistent organic pollutants on the sea urchin Psammechinus miliaris Ecotox Environ Safe 2011; 74: 2182-2192.

Arkoosh MR, Strickland S, Gaest AV, Ylitalo GM, Johnson L, Yanagida GK, Collier TK, Dietrich JP. Trends in organic pollutants and lipids in juvenile Snake River spring Chinook salmon with different outmigrating histories through the Lower Snake and Middle Columbia Rivers. Sci Total Environ 2011; 409: 5086-5100.

Arsenault G, Konstantinov A, Marvin CH, Macinnis G, McAlees A, McCrindle R, Riddell N, Tomy GT, Yeo B. Synthesis of the two minor isomers delta- and epsilon-1256910-hexabromocyclododecane present in commercial hexabromocyclo-dodecane. Chemosphere 2007; 68: 887-892.

Asante KA, Takahashi S, Itai T, Isobe T, Devanathan G, Muto M, Agyakwah SK, Adu-Kumi S, Subramanian A, Tanabe S. Occurrence of halogenated contaminants in inland and coastal fish from Ghana: Levels dietary exposure assessment and human health implications. Ecotox Environ Safe 2013; 94: 123-130. 
Ashizuka Y, Nakagawa R, Hori T, Yasutake D, Tobiishi K, Sasaki K. Determination of brominated flame retardants and brominated dioxins in fish collected from three regions of Japan. Mol Nutr Food Res 2008; 52 : $273-283$

ATSDR, 2004. Agency for Toxic Substances and Disease Registry. Toxicological profile for polybrominated biphenyls and polybrominated diphenyl ethers. US Department of Health and Human Services. Public Health Service, September, 2004.

Bae JH, Hwang SY, Yoon SH, Noh I, Lim SY. Comparison between ordinary and dark muscle extracts of yellowtail (Serila quinqueradiata) on chemical characteristics antiproliferative and antioxidant properties. $\mathbf{J}$ Food Technol 2011; 9: 99-105.

Balabanovich AI, Luda MP, Camino G, Hornung A. Thermal decomposition behavior of 12-bis-(246tribromophenoxy)ethane. J Anal Appl Pyrol 2003; 67: 95-107.

Barni MFS, Gonzalez M, Miglioranza KSB. Assessment of persistent organic pollutants accumulation and lipid peroxidation in two reproductive stages of wild silverside (Odontesthes bonariensis). Ecotox Environ Safe 2014; 99: 45-53.

Barón E, Rudolph I, Chiang G, Barra R, Eljarrat E, Barceló D. Occurrence and behavior of natural and anthropogenic (emerging and historical) halogenated compounds in marine biota from the Coast of Concepcion (Chile). Sci Total Environ 2013; 461-462: 258-264.

Barrento S, Marques A, Teixeira B, Mendes R, Bandarra N, Vaz-Pires P, Nunes ML. Chemical composition cholesterol fatty acid and amino acid in two populations of brown crab Cancer pagurus: Ecological and human health implications. J Food Compos Anal 2010; 23: 716-725.

Batterman S, Chernyak S, Gwynn E, Cantonwine D, Jia C, Begnoche L, Hickey JP. Trends of brominated diphenyl ethers in fresh and archived Great Lakes fish (1979-2005). Chemosphere 2007; 69: 444-457.

Bayen S, Lee HK, Obbard JP. Determination of polybrominated diphenyl ethers in marine biological tissues using microwave-assisted extraction. J Chromatogr A 2004; 1035: 291-294.

Bayen S, Lee HK, Obbard JP. Exposure and response of aquacultured oysters Crassostrea gigas to marine contaminants. Environ Res 2007; 103: 375-382.

Bellas J, Albentosa M, Vidal-Liñán L, Besada V, Franco MA, Fumega J, González-Quijano A, Viñas L, Beiras R. Combined use of chemical biochemical and physiological variables in mussels for the assessment of marine pollution along the N-NW Spanish coast. Marine Environ Res 2014; 96: 105-117.

Berg V, Zerihun MA, Jørgensen A, Lie E, Dale OB, Skaare JU, Lyche JL. High prevalence of infections and pathological changes in burbot (Lota lota) from a polluted lake (Lake Mjøsa Norway). Chemosphere 2013; 90 : $1711-1718$

Berntssen MHG, Julshamn K, Lundebye A-K. Chemical contaminants in aquafeeds and Atlantic salmon (Salmo salar) following the use of traditional- versus alternative feed ingredients. Chemosphere 2010; 78: 637646. 
Berntssen MHG, Maage A, Julshamn K, Oeye BE, Lundebye A-K. Carry-over of dietary organochlorine pesticides PCDD/Fs PCBs and brominated flame retardants to Atlantic salmon (Salmo salar L) fillets. Chemosphere 2012; 83: 95-103.

Binelli A, Guzzella L, Roscioli C. Levels and congener profiles of polybrominated diphenyl ethers (PBDEs) in Zebra mussels (D polymorpha) from Lake Maggiore (Italy). Environ Pollut 2008; 153: 610-617.

Blais JM, Charpentié S, Pick F, Kimpe LE, St Amand A Regnault-Roger C. Mercury polybrominated diphenyl ether organochlorine pesticide and polychlorinated biphenyl concentrations in fish from lakes along an elevation transect in the French Pyrénées Ecotox Environ Safe 2006; 63: 91-99.

Blanco SL, Martínez A, Porro C, Vieites LJM. Dietary uptake of polybrominated diphenyl ethers (PBDEs) occurrence and profiles in aquacultured turbots (Psetta maxima) from Galicia Spain. Chemosphere 2011; 85: 441-447.

Blocksom KA, Walters DM, Jicha TM, Lazorchak JM, Angradi TR, Bolgrien DW. Persistent organic pollutants in fish tissue in the mid-continental great rivers of the United States. Sci Total Environ 2010; 408: 1180-1189.

Bodin N, Abarnou A, Fraisse D, Defour S, Loizeau V, Le Guellec A-M, Philippon X. PCB PCDD/F and PBDE levels and profiles in crustaceans from the coastal waters of Brittany and Normandy (France). Mar Pollut Bull 2007; 54: 657-668.

Boer J, Wells DE. Pitfalls in the analysis of brominated flame retardants in environmental human and food samples - including results of three international interlaboratory studies. Trac - Trend Anal Chem 2006; 25 : $364-372$.

Bogdal C, Naef M, Schmid P, Kohler M, Zennegg M, Bernet D, Scheringer M, Hungerbühler K. Unexplained gonad alterations in whitefish (Coregonus spp) from Lake Thun Switzerland: Levels of persistent organic pollutants in different morphs. Chemosphere 2009; 74: 434-440.

Borghesi N, Corsolini S, Focardi S. Levels of polybrominated diphenyl ethers (PBDEs) and organochlorine pollutants in two species of Antarctic fish (Chionodraco hamatus and Trematomus bernacchii). Chemosphere 2008; 73: 155-160.

Borghesi N, Corsolini S, Leonards P, Brandsma S, de Boer J, Focardi S. Polybrominated diphenyl ether contamination levels in fish from the Antarctic and the Mediterranean Sea. Chemosphere 2009; 77: 693-698.

Braekevelt E, Tittlemier SA, Tomy GT. Direct measurement of octanol-water partition coefficients of some environmentally relevant brominated diphenyl ether congeners. Chemosphere 2003; 51: 563-567.

Bragigand V, Amiard-Triquet C, Parlier E, Boury P, Marchand P, Hourch ME. Influence of biological and ecological factors on the bioaccumulation of polybrominated diphenyl ethers in aquatic food webs from French estuaries. Sci Total Environ 2006; 368: 615-626.

Bratberg M, Olsvik PA, Edvardsen RB, Brekken HK, Vadla R, Meier S. Effects of oil pollution and persistent organic pollutants (POPs) on glycerophospholipids in liver and brain of male Atlantic cod (Gadus morhua). Chemosphere 2013; 90: 2157-2171. 
Braune BM, Gaston AJ, Elliott KH, Provencher JF, Woo KJ, Chambellant M, Ferguson SH, Letcher RJ. Organohalogen contaminants and total mercury in forage fish preyed upon by thick-billed murres in northern Hudson Bay. Mar Pollut Bull 2014; 78: 258-266.

Brown FR, Winkler J, Visita P, Dhaliwal J, Petreas M. Levels of PBDEs PCDDs PCDFs and coplanar PCBs in edible fish from California coastal waters. Chemosphere 2006; 64: 276-286.

Bruchajzer E, Frydrych B, Szymańska JA. Effect of repeated administration of hexabromobenzene and 1245Tetrabromobenzene on the levels of selected cytochromes in rat liver. Int J Occup Med Environ Health 2004; 17: $347-353$.

Bruchajzer E, Frydrych B, Szymańska JA. Octabromodiphenyl ether - porphyrogenicity after repeated administration to rats. Int J Occup Med Environ Health 2012; 25: 392-403.

Burreau S, Zebühr Y, Broman D, Ishaq R. Biomagnification of polychlorinated biphenyls (PCBs) and polybrominated diphenyl ethers (PBDEs) studied in pike (Esox lucius) perch (Perca fluviatilis) and roach (Rutilus rutilus) from the Baltic Sea. Chemosphere 2004; 55: 1043-1052.

Burreau S, Zebühr Y, Broman D, Ishaq R. Biomagnification of PBDEs and PCBs in food webs from the Baltic Sea and the northern Atlantic Ocean. Sci Total Environ 2006; 366: 659-672.

Bustnes JO, Lie E, Herzke D, Dempster T, Bjørn PA, Nygård T, Uglem I. Salmon Farms as a Source of Organohalogenated Contaminants in Wild Fish. Environ Sci Technol 2010; 44: 8736-8743.

Bustnes JO, Borgå K, Dempster T, Lie E, Nygård T, Uglem I. Latitudinal Distribution of Persistent Organic Pollutants in Pelagic and Demersal Marine Fish on the Norwegian Coast Environ. Sci Technol 2012; 46: 7836-7843.Byer JD, Lebeuf M, Alaee M, Stephen BR, Trottier S, Backus S, Keir M, Couillard CM, Casselman J, Hodson PV. Spatial trends of organochlorinated pesticides polychlorinated biphenyls and polybrominated diphenyl ethers in Atlantic Anguillid eels. Chemosphere 2013; 90: 1719-1728.

Byun G-H, Moon H-B, Choi J-H, Hwang J, Kang C-K. Biomagnification of persistent chlorinated and brominated contaminants in food web components of the Yellow Sea. Mar Pollut Bull 2013; 73: 210-219.

Carlson DL, De Vault DS, Swackhamer DL. On the Rate of Decline of Persistent Organic Contaminants in Lake Trout (Salvelinus namaycush) from the Great Lakes 1970-2003. Environ Sci Technol 2010; 44: 2004 2010 .

Carlsson P, Herzke D, Wedborg M, Gabrielsen GW. Environmental pollutants in the Swedish marine ecosystem with special emphasis on polybrominated diphenyl ethers (PBDE). Chemosphere 2011; 82: 12861292.

Carro AM, Lorenzo RA, Fernández F, Rodil R, Cela R. Multi-residue screening of chlorinated and brominated compounds from aquaculture samples using matrix solid-phase dispersion-gas chromatographymass spectrometry. J Chromatogr A 2005; 1071: 93-98.

Ceccatelli R, Faass O, Schlumpf M, Lichtensteiger W. Gene expression and estrogen sensitivity in rat uterus after developmental exposure to the polybrominated diphenylether PBDE 99 and PCB. Toxicology 2006; 220: 104-116. 
CEPA, 1999. Canadian Environmental Protection Act. March 3, 2000.

Chan WK, Chan KM. Disruption of the hypothalamic-pituitary-thyroid axis in zebrafish embryo-larvae following waterborne exposure to BDE-47 TBBPA and BPA. Aquat Toxicol 2012; 108: 106-111.

Chen C-Y, Tien C-J, Sun Y-M, Hsieh C-Y, Lee C-C. Influence of water quality parameters on occurrence of polybrominated diphenyl ether in sediment and sediment to biota accumulation. Chemosphere 2013; 90: 24202427.

Chen D, La Guardia MJ, Luellen DR, Harvey E, Mainor TM, Hale RC. Do Temporal and Geographical Patterns of HBCD and PBDE Flame Retardants in US Fish Reflect Evolving Industrial Usage? Environ Sci Technol 2011; 45: 8254-8261.

Chen X, Huang C, Wang X, Chen J, Bai C, Chen Y, Chen X, Dong Q, Yang D. BDE-47 disrupts axonal growth and motor behavior in developing zebrafish. Aquat Toxicol 2012a; 120-121: 35-44.

Chen L, Huang C, Hu C, Yu K, Yang L, Zhou B. Acute exposure to DE-71: Effects on locomotor behavior and developmental neurotoxicity in zebrafish larvae. Environ Toxicol Chem 2012b; 31: 2338-2344.

Chen M-L, Wang L, Chi YK, Mao C-C, Lung S-CC, Mao I-F. Polybrominated Diphenyl Ethers in Foodstuffs from Taiwan: Level and Human Dietary Exposure Assessment. Sci Total Environ 2012c; 431: 183-187.

Chen S-J, Ma Y-J, Wang J, Chen D, Luo X-J, Mai B-X. Brominated Flame Retardants in Children's Toys: Concentration Composition and Children's Exposure and Risk Assessment. Environ Sci Technol 2009; 43: 4200-4206.

Cheng J, Gu J, Ma J, Chen X, Zhang M, Wang W. Neurobehavioural effects redox responses and tissue distribution in rat offspring developmental exposure to BDE-99. Chemosphere 2009; 75: 963-968.

Cheng J, Mao L, Zhao Z, Shen M, Zhang S, Huang Q, Gao S. Bioaccumulation depuration and biotransformation of 44'-dibromodiphenyl ether in crucian carp (Carassius auratus). Chemosphere 2012; 86: $446-453$.

Cheung KC, Zheng JS, Leung HM, Wong MH. Exposure to polybrominated diphenyl ethers associated with consumption of marine and freshwater fish in Hong Kong. Chemosphere 2008; 70: 1707-1720.

Christiansen HE, Mehinto AC, Yu F, Perry R:W, Denslow ND, Maule AG, Mesa MG. Correlation of gene expression and contaminant concentrations in wild largescale suckers: A field-based study. Sci Total Environ 2013; 484: 379-389.

Colombo JC, Cappelletti N, Williamson M, Migoya MC, Speranza E, Sericano J, Muir DCG. Risk ranking of multiple-POPs in detritivorous fish from the Río de la Plata. Chemosphere 2011; 83: 882-889.

Costa LG. Contaminants in fish: risk-benefit considerations Arh Hig Rada Toksikol 2007; 58: 367-374.

Covaci A, Gheorghe A, Hulea O, Schepens P. Levels and distribution of organochlorine pesticides polychlorinated biphenyls and polybrominated diphenyl ethers in sediments and biota from the Danube Delta Romania. Environ Pollut 2006; 140: 136-149. 
Covaci A, Losada S, Roosens L, Vetter W, Santos FJ, Neels H, Storelli A, Storelli MM. Anthropogenic and Naturally Occurring Organobrominated Compounds in Two Deep-Sea Fish Species from the Mediterranean Sea. Environ Sci Technol 2008; 42: 8654-8660.

Covaci A, Harrad S, Abdallah MA-E, Ali N, Law RJ, Herzke D, Wit SA. Novel brominated flame retardants: A review of their analysis environmental fate and behavior. Environ Int 2011; 37: 532-556.CR, 2008. Canadian Regulations Polybrominated Diphenyl Ethers Regulations SOR/2008-218. June 19, 2008.

Crouse CC, Kelley RA, Trushenski JT, Lydy MJ. Use of alternative lipids and finishing feeds to improve nutritional value and food safety of hybrid striped bass. Aquaculture 2013; 408-409: 58-69.

Deng J, Yu L, Liu C, Yu K, Shi X, Yeung LWY, Lam PKS, Wu RSS, Zhou B. Hexabromocyclododecaneinduced developmental toxicity and apoptosis in zebrafish embryos. Aquat Toxicol 2009; 93: 29-36.

Dennehy C, Tsourounis C. A review of select vitamins and minerals used by postmenopausal women. Maturitas 2010; 66: 370-380.

Deshpande AD, Dockum BW. Polybrominated diphenyl ether congeners in the young-of-the-year bluefish Pomatomus saltatrix from several nursery habitats along the US Atlantic coastline. Mar Pollut Bull 2013; 77 : $237-250$.

Dias PS, Cipro CVZ, Taniguchi S, Montone RC. Persistent organic pollutants in marine biota of São Pedro and São Paulo Archipelago Brazil. Mar Pollut Bull 2013; 74: 435-440.

Dirtu AC, Abdallah M, Covaci A. Advances in the sample preparation of brominated flame retardants and other brominated compounds. Trac - Trend Anal Chem 2013; 43: 189-203.

Dodder NG, Maruyaa KA, Ferguson PL, Grace R, Klosterhaus S, La Guardia MJ, Lauenstein GG, Ramirez J. Occurrence of contaminants of emerging concern in mussels (Mytilus spp) along the California coast and the influence of land use storm water discharge and treated wastewater effluent. Mar Pollut Bull 2014; 81: 334 339.

Domingo JL. Omega-3 fatty acids and the benefits of fish consumption: Is all that glitters gold? Environ Int 2007; 33: 993-998.

Drouillard KG, Chan S, O'Rourke S, Haffner GD, Letcher RJ. Elimination of 10 polybrominated diphenyl ether (PBDE) congeners and selected polychlorinated biphenyls (PCBs) from the freshwater mussel Elliptio complanata. Chemosphere 2007; 69: 362-370.

Du M, Zhang D, Yan C, Zhang X. Developmental toxicity evaluation of three hexabromocyclododecane diastereoisomers on zebrafish embryos. Aquat Toxicol 2012; 112-113: 1-10.

ECB, 2001. European Chemicals Bureau. European Union Risk Assessment Report Diphenyl ether pentabromo derivative CAS No: 32534-81-9 EINECS No: 251-084-2. Office for Official Publications of the European Communities.

ECB, 2002. European Chemicals Bureau. European Union Risk Assessment Report Bis(pentabromophenyl) ether CAS No: 1163-19-5 EINECS No: 214-604-9 Final draft. 
ECB, 2003. European Chemicals Bureau. European Union Risk Assessment Report Diphenyl ether octabromo derivative CAS No: 32536-52-0 EINECS No: 251-087-9 Summary Report.

ECB, 2006. European Chemicals Bureau. European Commission - Joint Research Centre Institute for Health and Consumer Protection European Union Risk Assessment Report 22'66'-tetrabromo-44'isopropylidenediphenol (tetrabromobisphenol-A or TBBP-A) Part II - human health CAS No: 79-94-7 EINECS No: 201-236-9 Series: 4th Priority List Volume: 63.

ECD, 2003. Directive 2002/95/EC of the European Parliament and of the Council of 27 January 2003 on the restriction of the use of certain hazardous substances in electrical and electronic equipment. L 37/19.

ECD, 2008. EU Marine Strategy Framework Directive (2008/56/EC) Official Journal of the European Union. L 164, 19-40.

ECD, 2009. Official Journal of the European Union Commission Decision 2005/717/EC - Exemption of DecaBDE from the prohibition on use, C 116. May 9, 2008.

ECHA, 2012. European Chemicals Agency 246-tribromophenol. http://www.echa.europa.eu/ [online accessed in May 21, 2014].

Echols KR, Peterman PH, Hinck JE, Orazio CE. Polybrominated diphenyl ether metabolism in field collected fish from the Gila River Arizona USA - Levels possible sources and patterns. Chemosphere 2013; 90: $20-27$.

ECR, 2001. Commission Regulation (EU) No 466/2001 of 8 March 2001 setting maximum levels for certain contaminants in foodstuffs. March 3, 2001.

ECR, 2004. European Comission Regulation $N^{\circ} 853 / 2004$ of the european parliament and of the council laying down specific hygiene rules for on the hygiene of foodstuffs. April 29, 2004.

ECR, 2006a. Commission Regulation (EC) N N $^{\circ}$ 1883/2006 of 19 December 2006 laying down methods of sampling and analysis for the official control of levels of dioxins and dioxin-like PCBs in certain foodstuffs. December 20, 2006.

ECR, 2006b. Commission Regulation (EU) Nº1907/2006 concerning the Registration Evaluation Authorisation and Restriction of Chemicals (REACH) establishing a European Chemicals Agency amending Directive 1999/45/EC and repealing Council Regulation (EEC) No 793/93 and Commission Regulation (EC) N $1488 / 94$ as well as Council Directive 76/769/EEC and Commission Directives 91/155/EEC 93/67/EEC 93/105/EC and 2000/21/EC. December 18, 2006.

ECR, 2009. Commission Regulation (EC) N 552/2009 of 22 June 2009 amending Regulation (EC) No 1907/2006 of the European Parliament and of the Council on the Registration Evaluation Authorisation and Restriction of Chemicals (REACH) as regards Annex XVII. June 26, 2009.

ECR, 2010a. Commission Regulation (EU) $N^{\circ} 756 / 2010$ amending Regulation (EC) $N^{\circ} 850 / 2004$ of the European Parliament and of the Council on persistent organic pollutants as regards Annexes IV and V. August 24, 2010. 
ECR, 2010b. Commission Regulation (EU) No 757/2010 amending Regulation (EC) $N^{\circ} 850 / 2004$ of the European Parliament and of the Council on persistent organic pollutants as regards Annexes I and III. August $24,2010$.

ECR, 2011. Commission Regulation (EU) 1169/2011 on the provision of food information to consumers, amending Regulations (EC) $N^{\circ} 1924 / 2006$ and (EC) $N^{\circ} 1925 / 2006$ of the European Parliament and of the Council, and repealing Commission Directive 87/250/EEC, Council Directive 90/496/EEC, Commission Directive 1999/10/EC, Directive 2000/13/EC of the European Parliament and of the Council, Commission Directives 2002/67/EC and 2008/5/EC and Commission Regulation (EC) No 608/2004. October 25, 2011.

ECR, 2012a. Commission Regulation (EU) No 277/2012 amending Annexes I and II to Directive 2002/32/EC of the European Parliament and of the Council as regards maximum levels and action thresholds for dioxins and polychlorinated biphenyls. March 28, 2012.

ED, 2003. Directive 2002/96/EC of the European Parliament and of the Council of 27 January 2003 on waste electrical and electronic equipment (WEEE). February 13, 2003.

EFSA, 2010. European Food Safety Authority Scientific Opinion on Polybrominated Biphenyls (PBBs) in Food. EFSA Journal 8(10):1789.

EFSA, 2011a. European Food Safety Authority Scientific Opinion on Emerging and Novel Brominated Flame Retardants (BFRs) in Food. EFSA Journal 10(10): 2908.

EFSA, 2011b. European Food Safety Authority Scientific Opinion on Polybrominated Diphenyl Ethers (PBDEs) in Food. EFSA Journal 9(5):2156.

EFSA, 2011c. European Food Safety Authority cientific Opinion on Tetrabromobisphenol A (TBBPA) and its derivatives in food. EFSA Journal 9(12):2477.

EFSA, 2011d. European Food Safety Authority Scientific Opinion on Hexabromocyclododecanes (HBCDDs) in Food. EFSA Journal 9(7):2296.

EFSA, 2012b. European Food Safety Authority Scientific Opinion on Brominated Flame Retardants (BFRs) in Food: Brominated Phenols and their Derivatives. EFSA Journal 10(4):2634.

Egebäck A-L, Sellström U, McLachlan MS. Decabromodiphenyl ethane and decabromodiphenyl ether in Swedish background air. Chemosphere 2012; 86: 264-269.

Egloff C, Crump D, Chiu S, Manning G, McLaren KK, Cassone CG, Letcher RJ, Gauthier LT, Kennedy SW. In vitro and in ovo effects of four brominated flame retardants on toxicity and hepatic mRNA expression in chicken embryos. Toxicol Lett 2011; 207: 25-33.

Eljarrat E, de la Cal A, Raldua D, Duran C, Barceló D. Occurrence and Bioavailability of Polybrominated Diphenyl Ethers and Hexabromocyclododecane in Sediment and Fish from the Cinca River a Tributary of the Ebro River (Spain). Environ Sci Technol 2004; 38: 2603-2608.

Eljarrat E, de la Cal A, Raldua D, Duran C, Barcelo D. Brominated flame retardants in Alburnus alburnus from Cinca River Basin (Spain). Environ Pollut 2005; 133: 501-508. 
Eljarrat E, Labandeira A, Marsh G, Raldúa D, Barceló D. Decabrominated diphenyl ether in river fish and sediment samples collected downstream an industrial park. Chemosphere 2007; 69: 1278-1286.

Eljarrat E, Gorga M, Gasser M, Díaz-Ferrero J, Barceló D. Dietary exposure assessment of spanish citizens to hexabromocyclododecane through the diet. J Agr Food Chem 2014; 62: 2462-2468.Elsabee MZ, Abdou ES. Chitosan based edible films and coatings: A review. Mater Sci Eng: C 2013; 33: 1819-1841.

EPA, 2013a. Environmental Protection Agency Existing Chemicals. http://www,epagov/oppt/existingchemicals/pubs/2013wpractivities.html [online accessed in May 21, 2014].

EPA, 2013b. Environmental Protection Agency Toxics Release Inventory (TRI) Program. http://www2.epa.gov/toxics-release-inventory-tri-program/persistent-bioaccumulative-toxic-pbt-chemicalscovered-tri [online accessed in May 21, 2014].

Erdogrul Ö, Covaci A, Schepens P. Levels of organochlorine pesticides polychlorinated biphenyls and polybrominated diphenyl ethers in fish species from Kahramanmaras Turkey. Environ Int 2005; 31: 703-711.

Eriksson J, Rahm S, Green N, Bergman Å, Jakobsson E. Photochemical transformations of tetrabromobisphenol A and related phenols in water. Chemosphere 2004; 54: 117-126.

ESIS, 2014. European chemical Substances Information System hexabromobenzene. http://esis.jrc.ec.europa.eu/ [online accessed in May 21, 2014].

Eskenazi B, Chevrier J, Rauch SA, Kogut K, Harley KG, Johnson C, Trujillo C, Sjödin A, Bradman A. In Utero and Childhood Polybrominated Diphenyl Ether (PBDE) Exposures and Neurodevelopment in the CHAMACOS Study. Environ Health Persp 2013; 121(2): 257-262.

Evenset A, Christensen GN, Kallenborn R. Selected chlorobornanes polychlorinated naphthalenes and brominated flame retardants in Bjørnøya (Bear Island) freshwater biota. Environ Pollut 2005; 136: 419-430.

FAO, 2007. Food and Agriculture Organization FAO. Fisheries Circular N 972/4 Part 1, Rome.

FAO, 2011. Food and Agriculture Organization. Review of the state of world marine fishery resources 2011, Rome, 569.

FAO, 2012. Food and Agriculture Organization. The State of World Fisheries and Aquaculture 2012 Rome, 209.

FAO, 2013a. Food and Agriculture Organization. FISH TO 2030 - Prospects for Fisheries and Aquaculture. http://www.fao.org/docrep/019/i3640e/i3640e.pdf [online accessed in May 21, 2014].

FAO, 2013b. Food and Agriculture Organization. Yearbook of Fisheries Statistics - Appendix II - World fishery production: estimated value by groups of species. ftp://ftp.fao.org/fi/stat/summary/appIIybc.pdf [online accessed in May 21, 2014].

FAOSTAT, 2013. Food and Agriculture Organization. Statistic Division. http://faostatfao.org/site/610/DesktopDefault.aspx?PageID=610\#ancor [online accessed in May 21, 2014].

FAOSTAT, 2014. Food and Agriculture Organization. Statistic Division. http://faostatfaoorg/site/610/DesktopDefaultaspx?PageID=610\#ancor [online accessed in May 212014 ]. 
Feng M, Qu R, Wang C, Wang L, Wang Z. Comparative antioxidant status in freshwater fish Carassius auratus exposed to six current-use brominated flame retardants: A combined experimental and theoretical study. Aquat Toxicol 2013a; 140-141: 314-323.

Feng M, Li Y, Qu R, Wang L, Wang Z. Oxidative stress biomarkers in freshwater fish Carassius auratus exposed to decabromodiphenyl ether and ethane or their mixture. Ecotoxicology 2013b; 22: 11011110.Fernandes A, Dicks P, Mortimer D, Gem M, Smith F, Driffield M, White S, Rose M. Brominated and chlorinated dioxins PCBs and brominated flame retardants in Scottish shellfish: Methodology occurrence and human dietary exposure. Mol Nutr Food Res 2008; 52: 238 - 249.

Fernandes A, Mortimer D, Gem M, Dicks P, Smith F, White S, Rose M. Brominated dioxins (PBDD/Fs) and PBDEs in marine shellfish in the UK. Food Addit Contam 2009; 26: 918-927.

Fernandes AR, Rose M, Mortimer D, Carr M, Panton S, Smith F. Mixed brominated/chlorinated dibenzo-pdioxins dibenzofurans and biphenyls: Simultaneous congener-selective determination in food. J Chromatogr A 2011; 1218: 9279-9287.

Fery Y, Buschauer I, Salzig C, Lang P, Schrenk D. Technical pentabromodiphenyl ether and hexabromocyclododecane as activators of the pregnane-X-receptor (PXR). Toxicology 2009; 264: 45-51.

Fontana AR, Camargo A, Martinez LD, Altamirano JC. Dispersive solid-phase extraction as a simplified clean-up technique for biological sample extracts Determination of polybrominated diphenyl ethers by gas chromatography-tandem mass spectrometry. J Chromatogr A 2011; 1218: 2490-2496.

Frantzen S, Måge A, Iversen SA, Julshamn K. Seasonal variation in the levels of organohalogen compounds in herring (Clupea harengus) from the Norwegian Sea. Chemosphere 2011; 85: 179-187.

Fromme H, Körner W, Shahin N, Wanner A, Albrecht M, Boehmer S, Parlar H, Mayer R, Liebl B, Bolte G. Human exposure to polybrominated diphenyl ethers (PBDE) as evidenced by data from a duplicate diet study indoor air house dust and biomonitoring in Germany. Environ Int 2009; 35: 1125-1135.

Frouin H, Dangerfield N, Macdonald RW, Galbraith M, Crewe N, Shaw P, Mackas D, Ross PS. Partitioning and bioaccumulation of PCBs and PBDEs in marine plankton from the Strait of Georgia British Columbia Canada. Prog Oceanogr 2013; 115: 65-75.

Frydrych B, Szymańska JA, Sala M, Bruchajzer E. The effect of selected aromatic bromine derivatives on the activity of glutathione peroxidase and transferase. Int J Occup Med Environ Health 2005; 18: 127-132.

Gama AC, Sanatcumar P, Viana P, Barceló D, Bordado JC. The occurrence of polybrominated diphenyl ethers in river and coastal biota from Portugal. Chemosphere 2006; 64: 306-310.

Gao Z, Xu J, Xian Q, Feng J, Chen X, Yu H. Polybrominated diphenyl ethers (PBDEs) in aquatic biota from the lower reach of the Yangtze River East China. Chemosphere 2009; 75: 1273-1279.

Gassel M, Harwani S, Park J-S, Jahn A. Detection of nonylphenol and persistent organic pollutants in fish from the North Pacific Central Gyre. Mar Pollut Bull 2013; 73: 231-242. 
Germer S, Piersma AH, Ven L, Kamyschnikow A, Fery Y, Schmitz H-J, Schrenk D. Subacute effects of the brominated flame retardants hexabromocyclododecane and tertabromobisphenol A on hepatic cytochrome P450 levels in rats. Toxicology 2006; 218: 229-236.

Ghosh R, Hageman KJ, Björklund E. Selective pressurized liquid extraction of three classes of halogenated contaminants in fish. J Chromatogr A 2011; 1218: 7242-7247.

Giandomenico S, Spada L, Annicchiarico C, Assennato G, Cardellicchio N, Ungaro N, Di Leoa A. Chlorinated compounds and polybrominated diphenyl ethers (PBDEs) in mussels (Mytilus galloprovincialis) collected from Apulia Region coasts. Mar Pollut Bull 2013; 73: 243-251.

Gierón J, Grochowalski A, Chrzaszcz R. PBB levels in fish from the Baltic and North seas and in selected food products from Poland. Chemosphere 2010; 78: 1272-1278.

Gonnet M, Lethuaut L, Boury F. New trends in encapsulation of liposoluble vitamins. J Control Release 2010; 146: $276-290$.

Gorga M, Ginebreda A, Eljarrat E, Barceló D. Determination of PBDEs HBB PBEB DBDPE HBCD TBBPA and related compounds in sewage sludge from Catalonia (Spain). Sci Total Environ 2013; 444: 51-59.

Goscinny S, Vandevijvere S, Maleki M, Overmeire I, Windal I, Hanot V, Blaude M-N, Vleminckx C, Loco J. Dietary intake of hexabromocyclododecane diastereoisomers $(\alpha-\beta$ - and $\gamma$-HBCD) in the Belgian adult population. Chemosphere 2011; 84: 279-288.

Gouteux B, Alaee M, Mabury S, Muir D. Oligomeric BFRs a potential source for emerging brominated aromatic compounds. Organohalogen Compd 2006; 68: 659-662.

Goutte A, Chevreuil M, Alliot F, Chastel O, Cherel Y, Eléaume M, Massé G. Persistent organic pollutants in benthic and pelagic organisms off Adélie Land Antarctica. Mar Pollut Bull 2013; 77: 82-89.

Guérin T, Chekri R, Vastel C, Sirot V, Volatier J-L, Leblanc J-C, Noël L. Determination of 20 trace elements in fish and other seafood from the French market. Food Chem 2011; 127: 934-942.

Guerra P, De La Cal A, Marsh G, Eljarrat E, Barceló D. Transfer of hexabromocyclododecane from industrial effluents to sediments and biota: Case study in Cinca river (Spain). J Hydrol 2009; 369: 360-367.

Guo J, Wu F, Shen R, Zeng EY. Dietary intake and potential health risk of DDTs and PBDEs via seafood consumption in South China. Ecotox Environ Safe 2010; 73: 1812-1819.

Guo L, Qiu Y, Zhang G, Zheng GJ, Lam PKS, Li X. Levels and bioaccumulation of organochlorine pesticides (OCPs) and polybrominated diphenyl ethers (PBDEs) in fishes from the Pearl River estuary and Daya Bay South China. Environ Pollut 2008; 152: 604-611.

Hajšlová J, Pulkrabová J, Poustka J, Čajka T, Randák T. Brominated flame retardants and related chlorinated persistent organic pollutants in fish from river Elbe and its main tributary Vltava. Chemosphere 2007; 69: 1195-1203.

Hardy ML. A comparison of the properties of the major commercial PBDPO/PBDE product to those of major PBB and PCB products. Chemosphere 2002; 46: 717-728. 
Hardy ML, Krueger HO, Blankinship AS, Thomas S, Kendall TZ, Desjardins D. Studies and evaluation of the potential toxicity of decabromodiphenyl ethane to five aquatic and sediment organisms. Ecotox Environ Safe 2012; 75: 73-79.

Harmelin-Vivien M, Bodiguel X, Charmasson S, Loizeau V, Mellon-Duval C, Tronczyński J, Cossa D. Differential biomagnification of PCB PBDE Hg and Radiocesium in the food web of the European hake from the NW Mediterranean. Mar Pollut Bull 2012; 64: 974-983.

Harrad S, Abdallah MA-E, Rose NL, Turner SD, Davidson TA. Current-Use Brominated Flame Retardants in Water Sediment and Fish from English Lakes. Environ Sci Technol 2009; 43: 9077-9083.

Harrad S, Abdallah MAE. Brominated flame retardants in dust from UK cars - within vehicle spatial variability evidence for degradation and exposure implications. Chemosphere 2011; 82: 1240-1245.Hartmann PC, Burkhardt-Holmb P, Giger W. Occurrence of polybrominated diphenyl ethers (PBDEs) in brown trout bile and liver from Swiss rivers. Environ Pollut 2007; 146: 107-113.

Haug LS, Thomsen C, Lian VH, Becher G. Comparison of GC and LC determinations of hexabromocyclododecane in biological samples - Results from two interlaboratory comparison studies. Chemosphere 2008; 71: 1087-1092.

Haukås M, Mariussen E, Ruus A, Tollefsen KE. Accumulation and disposition of hexabromocyclododecane (HBCD) in juvenile rainbow trout (Oncorhynchus mykiss). Aquat Toxicol 2009a; 95: 144-151.

Haukås M, Hylland K, Berge JA, Nygård T, Mariussen E. Spatial diastereomer patterns of hexabromocyclododecane (HBCD) in a Norwegian fjord. Sci Total Environ 2009b; 407: 5907-5913.

Haukås M, Hylland K, Nygård T, Berge JA, Mariussen E. Diastereomer-specific bioaccumulation of hexabromocyclododecane (HBCD) in a coastal food web Western Norway. Sci Total Environ 2010; 408: 5910-5916.Hayward D, Wong J, Krynitsky AJ. Polybrominated diphenyl ethers and polychlorinated biphenyls in commercially wild caught and farm-raised fish fillets in the United States. Environ Res 2007; 103: 46-54.

He M-J, Luo X-J, Chen M-Y, Sun Y-X, Chen S-J, Mai BX. Bioaccumulation of polybrominated diphenyl ethers and decabromodiphenyl ethane in fish from a river system in a highly industrialized area South China. Sci Total Environ 2012; 419: 109-115.

He M-J, Luo X-J, Yu L-H, Wu J-P, Chen S-J, Mai B-X. Diasteroisomer and enantiomer-specific profiles of hexabromocyclododecane and tetrabromobisphenol $\mathrm{A}$ in an aquatic environment in a highly industrialized area South China: Vertical profile phase partition and bioaccumulation. Environ Pollut 2013; 179: 105-110.

Heeb NV, Schweizer WB, Mattrel P, Haag R, Gerecke AC, Schmid P, Zennegg M, Vonmont H. Regio- and steroeselective isomerization of hexabromocyclododecanes (HBCDs): kinetics and mechanism of $\gamma-$ to $\alpha-$ HBCD isomerization. Chemosphere 2008; 73: 1201-1210.

Hermanussen S, Matthews V, Päpke O, Limpus CJ, Gaus C. Flame retardants (PBDEs) in marine turtles dugongs and seafood from Queensland Australia. Mar Pollut Bull 2008; 57: 409-418.

Hiebl J, Vetter W. Detection of Hexabromocyclododecane and Its Metabolite Pentabromocyclododecene in Chicken Egg and Fish from the Official Food Control. J Agr Food Chem 2007; 55: 3319-3324. 
Hloušková V, Lanková D, Kalachová K, Hrádková P, Poustka J, Hajšlová J, Pulkrabová J. Occurrence of brominated flame retardants and perfluoroalkyl substances in fish from the Czech aquatic ecosystem. Sci Total Environ 2013; 461-462: 88-98.

Hoff PT, de Vijvera KV, Covaci A, Bervoets L, Moens L, Huyskens G, Goemans G, Belpaire C, Blust R, De Coen W. Perfluorooctane sulfonic acid and organohalogen pollutants in liver of three freshwater fish species in Flanders (Belgium): relationships with biochemical and organismal effects. Environ Pollut 2005; 137: 324 333.

Hornung MW, Zabel EW, Peterson RE. Toxic Equivalency Factors of Polybrominated Dibenzo-p-dioxin Dibenzofuran Biphenyl and Polyhalogenated Diphenyl Ether Congeners Based on Rainbow Trout Early Life Stage Mortality. Toxicol Appl Pharm 1996; 140: 227-234.

Hu G-C, Dai J-Y, Xu Z-C, Luo X-J, Cao H, Wang J-S, Mai B-X, Xu M-Q. Bioaccumulation behavior of polybrominated diphenyl ethers (PBDEs) in the freshwater food chain of Baiyangdian Lake North China. Environ Int 2010; 36: 309-315.

Hu X, Hu D, Song Q, Li J, Wang P. Determinations of hexabromocyclododecane (HBCD) isomers in channel catfish crayfish hen eggs and fish feeds from China by isotopic dilution LC-MS/MS. Chemosphere 2011; 82: 698-707.

Huang F, Wen S, Lia J, Zhong Y, Zhao Y, Wu Y. The human body burden of polybrominated diphenyl ethers and their relationships with thyroid hormones in the general population in Northern China. Sci Total Environ 2014; 466-467: 609-615.

Huang G-Y, Ying G-G, Liang Y-Q, Zhao J-L, Yang B, Liu S, Liu Y-S. Hormonal effects of tetrabromobisphenol A using a combination of in vitro and in vivo assays. Comp Biochem Phys C 2013; 157 : $344-351$.

Ibhazehiebo K, Iwasaki T, Okano-Uchida T, Shimokawa N, Ishizaki Y, Koibuchi N. Suppression of thyroid hormone receptor-mediated transcription and disruption of thyroid hormone-induced cerebellar morphogenesis by the polybrominated biphenyl mixture BP-6. Neurotoxicology 2011; 32: 400-409.

Ikonomou MG, Fernandez MP, Hickman ZL. Spatio-temporal and species-specific variation in PBDE levels/patterns in British Columbia's coastal waters. Environ Pollut 2006; 140: 355-363.

Ilyas M, Sudaryanto A, Setiawan IE, Riyadi AS, Isobe T, Tanabe S. Characterization of polychlorinated biphenyls and brominated flame retardants in sludge sediment and fish from municipal dumpsite at Surabaya Indonesia. Chemosphere 2013; 93: 1500-1510.

IPCS, 1994. International Program on Chemical Safety. Brominated Diphenyl Ethers International Program on Chemical Safety. Environmental Health Criteria 162, World Health Organization, Geneva.

Ismail N, Gewurtz SB, Pleskach K, Whittle DM, Helm PA, Marvin CH, Tomy GT. Brominated and chlorinated flame retardants in Lake Ontario Canada lake trout (Salvelinus namaycush) between 1979 and 2004 and possible influences of food-web changes. Environ Toxicol Chem 2009; 28: 910-920. 
Isobe T, Ogawa SP, Ramu K, Sudaryanto A, Tanabe S. Geographical distribution of non-PBDE-brominated flame retardants in mussels from Asian coastal waters. Environ Sci Pollut R 2012; 19: 3107-3117.

Isosaari P, Lundebye AK, Ritchie G, Lie O, Kiviranta H, Vartiainen T. Dietary accumulation efficiencies and biotransformation of polybrominated diphenyl ethers in farmed Atlantic salmon (Salmo salar). Food Addit Contam 2005; 22: 829-837.

Isosaari P, Hallikainen A, Kiviranta H, Vuorinen PJ, Parmanne R, Koistinen J, Vartiainen T. Polychlorinated dibenzo-p-dioxins dibenzofurans biphenyls naphthalenes and polybrominated diphenyl ethers in the edible fish caught from the Baltic Sea and lakes in Finland. Environ Pollut 2006; 141: 213-225.

Jacobs MN, Covaci A, Gheorghe A, Schepens P. Time Trend Investigation of PCBs PBDEs and Organochlorine Pesticides in Selected n-3 Polyunsaturated Fatty Acid Rich Dietary Fish Oil and Vegetable Oil Supplements Nutritional Relevance for Human Essential n-3 Fatty Acid Requirements. J Agr Food Chem 2004; 52: 1780-1788.

James MO, Little PJ. Polyhalogenated biphenyls and phenobarbital: Evaluation as inducers of drug metabolizing enzymes in the sheepshead Archosargus probatocephalus. Chem-Biol Interact 1981; 36: 229248.

Janák K, Covaci A, Voorspoels S, Becher G. Hexabromocyclododecane in Marine Species from the Western Scheldt Estuary: Diastereoisomer- and Enantiomer-Specific Accumulation. Environ Sci Technol 2005; 39: 1987-1994.

Jeong GH, Hwang NR, Hwang E-H, Lee B-C, Yoon J. Hexabromocyclododecanes in crucian carp and sediment from the major rivers in Korea. Sci Total Environ 2014; 470-471: 1471-1478.

Jiang J, Shi S, Chen T. Occurrence of polybrominated diphenyl ethers in fish and shellfish downstream from electronic-waste recycling plants. J Environ Sci 2010; 22: 723-730.

Jin J, Liu W, Wang Y, Tang XY. Levels and distribution of polybrominated diphenyl ethers in plant shellfish and sediment samples from Laizhou Bay in China. Chemosphere 2008; 71: 1043-1050.

Johansson I, Héas-Moisan K, Guiot N, Munschy C, Tronczyński J. Polybrominated diphenyl ethers (PBDEs) in mussels from selected French coastal sites: 1981-2003. Chemosphere 2006; 64: 296-305.

Johnson PI, Stapleton HM, Mukherjee B, Hauser R, Meeker JD. Associations between brominated flame retardants in house dust and hormone levels in men. Sci Total Environ 2013; 445-446: 177-184.

Johnson-Restrepo B, Adams DH, Kannan K. Tetrabromobisphenol A (TBBPA) and hexabromocyclododecanes (HBCDs) in tissues of humans dolphins and sharks from the United States. Chemosphere 2008; 70: 1935-1944.

Julshamn K, Duinker A, Berntssen M, Nilsen BM, Frantzen S, Nedreaas K, Maage A. A baseline study on levels of polychlorinated dibenzo-p-dioxins polychlorinated dibenzofurans non-ortho and mono-ortho PCBs non-dioxin-like PCBs and polybrominated diphenyl ethers in Northeast Arctic cod (Gadus morhua) from different parts of the Barents Sea. Mar Pollut Bull 2013; 75: 250-258. 
Jürgens MD, Johnson AC, Jones KC, Hughes D, Lawlor AJ. The presence of EU priority substances mercury hexachlorobenzene hexachlorobutadiene and PBDEs in wild fish from four English rivers. Sci Total Environ 2013; 461-462: 441-452.

Kakimoto K, Akutsu K, Konishi Y, Tanaka Y. Evaluation of hexabromocyclododecane in fish and marine mammal oil supplements. Food Chem 2008; 107: 1724-1727.

Kakimoto K, Nagayoshi H, Takagi S, Akutsu K, Konishi Y, Kajimura K, Hayakawa K, Toriba A. Inhalation and dietary exposure to Dechlorane Plus and polybrominated diphenyl ethers in Osaka Japan. Ecotox Environ Safe 2014; 99: 69-73.

Kakimoto K, Nagayoshi H, Yoshida J, Akutsu K, Konishi Y, Toriba A, Hayakawa K. Detection of Dechlorane Plus and brominated flame retardants in marketed fish in Japan. Chemosphere 2012; 89: 416-419.

Kefeni KK, Okonkwo JO, Olukunle OI, Botha BM. Brominated flame retardants: sources distribution exposure pathways and toxicity. Environ Rev 2011; 19: 238-253.

Kelly BC, Ikonomou MG, Blair JD, Gobas FAPC. Bioaccumulation behaviour of polybrominated diphenyl ethers (PBDEs) in a Canadian Arctic marine food web. Sci Total Environ 2008; 401: 60-72.

Kierkegaard A, Bignert A, Sellström U, Olsson M, Asplunda L, Janssona B, de Wit CA. Polybrominated diphenyl ethers (PBDEs) and their methoxylated derivatives in pike from Swedish waters with emphasis on temporal trends 1967-2000. Environ Pollut 2004; 130: 187-198.

Kierkegaad A, Sellström U, McLachlan, MS. Environmental analysis of higher brominated diphenyl ethers and decabromodiphenyl ethane. J Chromatogr A 2009; 1216: 364-375.Kim GB, Stapleton HM. PBDEs methoxylated PBDEs and HBCDs in Japanese common squid (Todarodes pacificus) from Korean offshore waters. Mar Pollut Bull 2010; 60: 935-940.

Kim S, Park J, Kim H-J, Lee J J, Choi G, Choi S, Kim S, Kim S Y, Moon H-B, Kim S, Choi K. Association between several persistent organic pollutants and thyroid hormone levels in serum among the pregnant women of Korea. Environ Int 2013; 59: 442-448.

Klosterhaus SL, Stapleton HM, La Guardia MJ, Greig DJ. Brominated and chlorinated flame retardants in San Francisco Bay sediments and wildlife. Environ Int 2012; 47: 56-65.

Kodavanti PRS, Coburn CG, Moser VC, MacPhail RC, Fenton SE, Stoker TE, Rayner JL, Kannan K, Birnbaum LS. Developmental Exposure to a Commercial PBDE Mixture DE-71: Neurobehavioral Hormonal and Reproductive Effects. Toxicol Sci 2010; 116: 297-312.

Koenig S, David Huertas D, Fernández P. Legacy and emergent persistent organic pollutants (POPs) in NW Mediterranean deep-sea organisms. Sci Total Environ 2013; 443: 358-366.

Koistinen J, Kiviranta H, Ruokojärvi P, Parmanne R, Verta M, Hallikainen A, Vartiainen T. Organohalogen pollutants in herring from the northern Baltic Sea: Concentrations congener profiles and explanatory factors. Environ Pollut 2008; 154: 172-183.

Koistinen J, Herve S, Ruokojärvi P, Koponen J, Vartiainen T. Persistent organic pollutants in two Finnish watercourses: Levels congener profiles and source estimation by mussel incubation. Chemosphere 2010; 80: 
625-633.Köppen R, Becker R, Esslinger S, Nehls I. Enantiomer-specific analysis of hexabromocyclododecane in fish from Etnefjorden (Norway). Chemosphere 2010; 80: 1241-1245.

Kris-Etherton PM, Harris WS, Appel LJ. Fish consumption fish oil omega-3 fatty acids and cardiovascular disease. Circulation 2002; 106: 2747-2757.

Kuiper RV, Cantón RF, Leonards PEG, Jenssend BM, Dubbeldame M, Wester PW, Berg M, Vos JG, Vethaakg AD. Long-term exposure of European flounder (Platichthys flesus) to the flame-retardants tetrabromobisphenol A (TBBPA) and hexabromocyclododecane (HBCD). Ecotox Environ Safe 2007; 67: 349360 .

Kuiper RV, Vethaak AD, Cantón RF, Anselmo H, Dubbeldamd M, van den Brandhof E-J, Leonards PEG, Wester PW, van den Berg M. Toxicity of analytically cleaned pentabromodiphenylether after prolonged exposure in estuarine European flounder (Platichthys flesus) and partial life-cycle exposure in fresh water zebrafish (Danio rerio). Chemosphere 2008; 73: 195-202.

La Guardia MJ, Hale RC, Harvey E, Mainor TM, Ciparis S. In Situ Accumulation of HBCD PBDEs and Several Alternative Flame-Retardants in the Bivalve (Corbicula fluminea) and Gastropod (Elimia proxima). Environ Sci Technol 2012; 46: 5798-5805.

Labadie P, Alliot F, Bourges C, Desportes A, Chevreuil M. Determination of polybrominated diphenyl ethers in fish tissues by matrix solid-phase dispersion and gas chromatography coupled to triple quadrupole mass spectrometry: Case study on European eel (Anguilla anguilla) from editerranean coastal lagoons. Anal Chim Acta 2010; 675: 97-105.

Labandeira A, Eljarrat E, Barceló D. Congener distribution of polybrominated diphenyl ethers in feral carp (Cyprinus carpio) from the Llobregat River Spain. Environ Pollut 2007; 146: 188-195.

Lacorte S, Raldúa D, Martínez E, Navarro A, Diez S, Bayona JM, Barceló D. Pilot survey of a broad range of priority pollutants in sediment and fish from the Ebro river basin (NE Spain). Environ Pollut 2006; 140: 471482.

Lal V, Bridgen P, Votadroka W, Raju R, Aalbersberg W. Characterization of organochlorine pesticides brominated flame retardants and dioxin-like compounds in shellfish and eel from Fiji. Sci Total Environ 2014; 491-492: 200-204.

Lara AB, Caballo C, Sicilia MD, Rubio S. Enantiomer-specific determination of hexabromocyclododecane in fish by supramolecular solvent-based single-step sample treatment and liquid chromatography-tandem mass spectrometry. Anal Chim Acta 2012; 752: 62-68.

Larsen R, Eilertsen K-E, Elvevoll EO. Health benefits of marine foods and ingredients. Biotechnol Adv 2011; 29: $508-518$.

Lavandier R, Quinete N, Hauser-Davis RA, Dias PS, Taniguchi S, Montone R, Moreira I. Polychlorinated biphenyls (PCBs) and Polybrominated Diphenyl ethers (PBDEs) in three fish species from an estuary in the southeastern coast of Brazil. Chemosphere 2013; 90: 2435-2443. 
Law K, Halldorson T, Danell R, Stern G, Gewurtz S, Alaee M, Marvin C, Whittle M, Tomy G. Bioaccumulation and trophic transfer of some brominated flame retardants in a Lake Winnipeg (Canada) food web. Environ Toxicol Chem 2006; 25: 2177-2186.

Lee HJ, Kim GB, Lee RF. Genotoxicity and development effects of brominated flame retardant PBDEs and UV-exposed PBDEs on grass shrimp (Palaemonetes pugio) embryo. Mar Pollut Bull 2012; 64: 2892-2895.

Lee S, Kannan K, Moon H-B. Assessment of exposure to polybrominated diphenyl ethers (PBDEs) via seafood consumption and dust ingestion in Korea. Sci Total Environ 2013; 443: 24-30.

Leeuwen SPJ, de Boer J. Brominated flame retardants in fish and shellfish - levels and contribution of fish consumption to dietary exposure of Dutch citizens to HBCD. Mol Nutr Food Res 2008; 52: 194 - 203.

Leeuwen SPJ, van Velzen MJM, Swart CP, van der Veen I, Traag WA, de Boer J. Halogenated Contaminants in Farmed Salmon Trout Tilapia Pangasius and Shrimp. Environ Sci Technol 2009; 43: 4009-4015.

Li Q, Yan C, Luo Z, Zhang X. Occurrence and levels of polybrominated diphenyl ethers (PBDEs) in recent sediments and marine organisms from Xiamen offshore areas China. Mar Pollut Bull 2010; 60: 464-469.

Li Y, Zhou Q, Wang Y, Xie X. Fate of tetrabromobisphenol A and hexabromocyclododecane brominated flame retardants in soil and uptake by plants. Chemosphere 2011; 82: 204-209.

Lin Z, Tu F, Ma Y, Chen M, Zhang L, Sun R, Zou X, Li X, Chen Z. Determination of Five Polybrominated Diphenyl Ethers Residues in Deep-Sea Fish Oil Using Gas Chromatography-Negative Chemical Ionization/Mass Spectrometry. Chin J Chromatogr 2007; 25: 262-267.

Liu Q, Shi J, Sun J, Wang T, Zeng L, Zhu N, Jiang G. Graphene-assisted matrix solid-phase dispersion for extraction of polybrominated diphenyl ethers and their methoxylated and hydroxylated analogs from environmental samples. Anal Chim Acta 2011a; 708: 61-68.

Liu Y, Zheng GJ, Yu H, Martin M, Richardson BJ, Lam MHW, Lam PKS. Polybrominated diphenyl ethers (PBDEs) in sediments and mussel tissues from Hong Kong marine waters. Mar Pollut Bull 2005; 50: 1173 1184.

Liu Y-P, Li J-G, Zhao Y-F, Wen S, Huang F-F, Wu Y-N. Polybrominated diphenyl ethers (PBDEs) and indicator polychlorinated biphenyls (PCBs) in marine fish from four areas of China. Chemosphere 2011b; 83: $168-174$.

Loret J. Human health benefits supplied by Mediterranean marine biodiversity. Mar Pollut Bull 2010; 60: $1640-1646$.

Löfstrand K, Liu X, Lindqvist D, Jensen S, Asplund L. Seasonal variations of hydroxylated and methoxylated brominated diphenyl ethers in blue mussels from the Baltic Sea. Chemosphere 2011; 84: 527-532.

Losada S, Santos FJ, Galceran MT. Selective pressurized liquid extraction of polybrominated diphenyl ethers in fish. Talanta 2009a; 80: 839-845.

Losada S, Roach A, Roosens L, Santos FJ, Galceran MT, Vetter W, Neels H, Covaci A. Biomagnification of anthropogenic and naturally-produced organobrominated compounds in a marine food web from Sydney Harbour Australia. Environ Int 2009b; 35: 1142-1149. 
Losada S, Santos FJ, Covaci A, Galceran MT. Gas chromatography-ion trap tandem mass spectrometry method for the analysis of methoxylated polybrominated diphenyl ethers in fish. J Chromatogr A 2010a; 1217: 5253-5260.Losada S, Parera J, Abalos M, Abad E, Santos FJ, Galceran MT. Suitability of selective pressurized liquid extraction combined with gas chromatography-ion-trap tandem mass spectrometry for the analysis of polybrominated diphenyl ethers. Anal Chim Acta 2010b; 678: 73-81.

Lozano N, Rice CP, Pagano J, Zintek L, Barber LB, Murphy EW, Nettesheim T, Minarik T, Schoenfuss HL. Concentration of organic contaminants in fish and their biological effects in a wastewater-dominated urban stream. Sci Total Environ 2012; 420: 191-201.

Luo Q, Cai ZW, Wong MH. Polybrominated diphenyl ethers in fish and sediment from river polluted by electronic waste. Sci Total Environ 2007a; 383: 115-127.

Luo Q, Wong M, Cai Z. Determination of polybrominated diphenyl ethers in freshwater fishes from a river polluted by e-wastes. Talanta 2007b; 72: 1644-1649.

Luo X-J, Zeng Y-H, Chen H-S, Wu J-P, Chen S-J, Mai B-X. Application of compound-specific stable carbon isotope analysis for the biotransformation and trophic dynamics of PBDEs in a feeding study with fish. Environ Pollut 2013a; 176: 36-41.

Luo X-J, Ruan W, Zeng Y-H, Liu H-Y, Chen S-J, Wu J-P, Mai B-X. Trophic dynamics of hexabromocyclododecane diastereomers and enantiomers in fish in a laboratory feeding study. Environ Toxicol Chem 2013b; 32: 2565-2570.Ma X, Zhang H, Yao Z, Zhao X, Wang L, Wang Z, Chen J, Chen J. Bioaccumulation and trophic transfer of polybrominated diphenyl ethers (PBDEs) in a marine food web from Liaodong Bay North China. Mar Pollut Bull 2013; 74: 110-115.

Mackintosh SA, Pérez-Fuentetaja A, Zimmerman LR, Pacepavicius G, Clapsadl M, Alaee M, Aga DS. Analytical performance of a triple quadrupole mass spectrometer compared to a high resolution mass spectrometer for the analysis of polybrominated diphenyl ethers in fish. Anal Chim Acta 2012; 747: 67-75.

Madenjian CP, Trombka AW, Rediske RR, Jude DJ, O'Keefe JP. Sex difference in polybrominated diphenyl ether concentrations of walleyes. J Great Lakes Res 2012; 38: 167-175.

Magalhães CA, Taniguchi S, Cascaes MJ, Montone RC. PCBs PBDEs and organochlorine pesticides in crabs Hepatus pudibundus and Callinectes danae from Santos Bay State of São Paulo Brazil. Mar Pollut Bull 2012; 64: $662-667$.

Malarvannan G, Belpaire C, Geeraerts C, Eulaers I, Neels H, Covaci A. Assessment of persistent brominated and chlorinated organic contaminants in the European eel (Anguilla anguilla) in Flanders Belgium: Levels profiles and health risk. Sci Total Environ 2014; 482-483: 222-233.

Malavia J, Santos FJ, Galceran MT. Simultaneous pressurized liquid extraction and clean-up for the analysis of polybrominated biphenyls by gas chromatography-tandem mass spectrometry. Talanta 2011; 84: 1155-1162.

Mariottini M, Corsi I, Torre CD, Caruso T, Bianchini A, Nesi I, Focardi S. Biomonitoring of polybrominated diphenyl ether (PBDE) pollution: A field study. Comp Biochem Phys C 2008; 148: 80-86. 
Mariussen E, Fjeld E, Breivik K, Steinnes E, Borgen A, Kjellberg G, Schlabach M. Elevated levels of polybrominated diphenyl ethers (PBDEs) in fish from Lake Mjøsa Norway. Sci Total Environ 2008; 390: 132141.

Marques A Lourenço HM Nunes ML Roseiro C Santos C Barranco A Rainieri S Langerholc T Cencic A. New tools to assess toxicity bioaccessibility and uptake of chemical contaminants in meat and seafood. Food Res Int 2011; 44: 510-522.

Martí-Cid R, Bocio A, Llobet JM, Domingo JL. Intake of chemical contaminants through fish and seafood consumption by children of Catalonia Spain: Health risks. Food Chem Toxicol 2007; 45: 1968-1974.

Martínez A, Ramil M, Montes R, Hernanz D, Rubí E, Rodríguez I, Cela-Torrijos R. Development of a matrix solid-phase dispersion method for the screening of polybrominated diphenyl ethers and polychlorinated biphenyls in biota samples using gas chromatography with electron-capture detection. J Chromatogr A 2005; 1072: 83-91.

Mas S, Juan A, Tauler R, Olivieri AC, Escandar GM. Application of chemometric methods to environmental analysis of organic pollutants: A review. Talanta 2010; 80: 1052-1067.

McCormick JM, Paiva MS, Häggblom MM, Cooper KR, White LA. Embryonic exposure to tetrabromobisphenol A and its metabolites bisphenol A and tetrabromobisphenol A dimethyl ether disrupts normal zebrafish (Danio rerio) development and matrix metalloproteinase expression. Aquat Toxicol 2010; 100: $255-262$.

McHugh B, Poole R, Corcoran J, Anninou P, Boyle B, Joyce E, Foley MB, McGovern E. The occurrence of persistent chlorinated and brominated organic contaminants in the European eel (Anguilla anguilla) in Irish waters. Chemosphere 2010; 79: 305-313.

Meng X-Z, Xiang N, Duan Y-P, Chen L, Zeng EY. Hexabromocyclododecane in consumer fish from South China: Implications for human exposure via dietary intake. Environ Toxicol Chem 2012; 31: 1424-1430.

Miniero R, Brambilla G, Chiaravalle E, Mangiacotti M, Brizzi G, Ingelido AM, Abate V, Cascone V, Ferri F, Iacovella N, di Domenico A. Chemometric data analysis application to Sparus aurata samples from two offshore farming plants along the Apulian (Italy) coastline. Chemosphere 2011; 85: 465-472.

Miyake Y, Jiang Q, Yuan W, Hanari N, Okazawa T, Wyrzykowska B, So MK, Lam PKS, Yamashita N. Preliminary health risk assessment for polybrominated diphenyl ethers and polybrominated dibenzo-pdioxins/furans in seafood from Guangzhou and Zhoushan China. Mar Pollut Bull 2008; 57: 357-364.

Mizukawa K, Takada H, Takeuchi I, Ikemoto T, Omori K, Tsuchiya K. Bioconcentration and biomagnification of polybrominated diphenyl ethers (PBDEs) through lower-trophic-level coastal marine food web. Mar Pollut Bull 2009; 58: 1217-1224.

Mizukawa K, Yamada T, Matsuo H, Takeuchi I, Tsuchiya K, Takada H. Biomagnification and debromination of polybrominated diphenyl ethers in a coastal ecosystem in Tokyo Bay. Sci Total Environ 2013; 449: 401409. 
Möller A, Xie Z, Caba A, Sturm R, Ebinghaus R. Occurrence and air-seawater exchange of brominated flame retardants and Dechlorane Plus in the North Sea. Atmos Environ 2012; 46: 346-353.

Montie EW, Letcher RJ, Reddy CM, Moore MJ, Rubinstein B, Hahn ME. Brominated flame retardants and organochlorine contaminants in winter flounder harp and hooded seals and North Atlantic right whales from the Northwest Atlantic Ocean. Mar Pollut Bull 2010; 60: 1160-1169.

Montory M, Barra R. Preliminary data on polybrominated diphenyl ethers (PBDEs) in farmed fish tissues (Salmo salar) and fish feed in Southern Chile. Chemosphere 2006; 63: 1252-1260.

Montory M, Habit E, Fernandez P, Grimalt JO, Barra R. PCBs and PBDEs in wild Chinook salmon (Oncorhynchus tshawytscha) in the Northern Patagonia Chile. Chemosphere 2010; 78: 1193-1199.

Montory M, Habit E, Fernandez P, Grimalt JO, Barra R. Polybrominated diphenyl ether levels in wild and farmed Chilean salmon and preliminary flow data for commercial transport. J Environ Sci 2012; 24: $221-227$.

Moon H-B, Kannan K, Lee S-J, Choi M. Polybrominated diphenyl ethers (PBDEs) in sediment and bivalves from Korean coastal waters. Chemosphere 2007; 66: 243-251.

Morris S, Allchin CR, Zegers BN, Haftka JJH, Boon JP, Belpaire C, Leonards PEG, Leeuwen SPJ, Boer J. Distribution and Fate of HBCD and TBBPA Brominated Flame Retardants in North Sea Estuaries and Aquatic Food Webs. Environ Sci Technol 2004; 38: 5497-5504.

Muenhor D, Harrad S, Ali N, Covaci A. Brominated flame retardants (BFRs) in air and dust from electronic waste storage facilities in Thailand. Environ Int 2010; 36: 690-698.

Muirhead EK, Skillman AD, Hook SE, Schultz IR. Oral Exposure of PBDE-47 in Fish: Toxicokinetics and Reproductive Effects in Japanese Medaka (Oryzias latipes) and Fathead Minnows (Pimephales promelas). Environ Sci Technol 2006; 40: 523-528.

Munschy C, Héas-Moisan K, Tixier C, Boulesteix L, Morin J. Classic and novel brominated flame retardants (BFRs) in common sole (Solea solea L) from main nursery zones along the French coasts. Sci Total Environ 2011; 409: 4618-4627.

Munschy C, Marchand P, Venisseau A, Veyrand B, Zendong Z. Levels and trends of the emerging contaminants HBCDs (hexabromocyclododecanes) and PFCs (perfluorinated compounds) in marine shellfish along French coasts. Chemosphere 2013; 91: 233-240.

Nácher-Mestre J, Serrano R, Hernández F, Benedito-Palos L, Pérez-Sánchez J. Gas chromatography-mass spectrometric determination of polybrominated diphenyl ethers in complex fatty matrices from aquaculture activities. Anal Chim Acta 2010; 664: 190-198.

Nakagawa R, Murata S, Ashizuka Y, Shintani Y, Hori T, Tsutsumi T. Hexabromocyclododecane determination in seafood samples collected from Japanese coastal areas. Chemosphere 2010; 81: 445-452.

Nakari T, Huhtala S. Comparison of toxicity of congener-153 of PCB PBB and PBDE to Daphnia magna. Ecotox Environ Safe 2008; 71: 514-518. 
Nakari T, Huhtela S. In vivo and in vitro toxicity of decabromodiphenyl ethane a flame retardant. Environ Toxicol 2010; 25: 333-338.

Ni H-G, Ding C, Lu S-Y, Yin X-L, Samuel SO. Food as a main route of adult exposure to PBDEs in Shenzhen China. Sci Total Environ 2012; 437: 10-14.

Ni H-G, Zeng H. HBCD and TBBPA in particulate phase of indoor air in Shenzhen China. Sci Total Environ 2013; 458-460: 15-19.

NIES, 1998. National Institute for Environmental Studies. Strategic Programs on Environmental Endocrine Disruptors (SPEED’98). Analytical methods for endocrine disruptors. Japan , October, 1998.

Nilsen E, Zaugg S, Alvarez D, Morace J, Waite I, Counihan T, Hardiman J, Torres L, Patiño R, Mesa M, Grove R. Contaminants of legacy and emerging concern in largescale suckers (Catostomus macrocheilus) and the foodweb in the lower Columbia River Oregon and Washington USA. Sci Total Environ 2014; 484: 344 352.

Nomeir AA, Markham PM, Ghanayem BI, Chadwick M. Disposition of the flame-retardant 12-bis(246tribromophenoxy)ethane in rats following administration in the diet. Drug Metab Dispos 1993; 21: 209-214.

Nomiyama K, Uchiyama Y, Horiuchi S, Eguchi A, Mizukawa H, Hirata SH, Shinohara R, Tanabe S. Organohalogen compounds and their metabolites in the blood of Japanese amberjack (Seriola quinqueradiata) and scalloped hammerhead shark (Sphyrna lewini) from Japanese coastal waters. Chemosphere 2011; 85: 315321.

Nordic Council of Ministers, 2011. Brominated Flame Retardants (BFR) in the Nordic Environment Schlabach M, Remberger M, Brorström-Lundén E, Norström K, Kaj L, Andersson H, Herzke D, Borgen A, Harju M TemaNord 2011: 528 Nordic Council of Ministers Copenhagen, Denmark.

NPCA, 2009. Norwegian Pollution Control Authority. Current state of knowledge and monitoring requirements - Emerging "new" brominated flame retardants in flame retarded products and the environment (TA-2462/2008).

NTP, 1993. National Toxicology Program. NTP technical report on the perinatal toxicology and carcinogenesis studies of polybrominated biphenyls (Firemaster FF-1) (CAS No 67774-32-7) in F344/N rats and B6C3F1 mice (feed studies) Research Triangle Park NC US Department of Health and Human Services National Toxicology Program (NTP TR 398 NIH publication No 92-2853) .

Nunes ML, Bandarra N, Oliveira L, Batista I, Antónia M. Composition and nutritional value of fishery products consumed in Portugal. In: Luten JB, Jacobsen C, Bekaret K, Sæbø A, Oehlenschläger J, editors. Seafood research from fish to dish quality safety and processing of wild and farmed fish. Wageningen: Wageningen Academic Press; 2009. p. 41-57.

O'Dell BL, Sunde RA. Handbook of nutritionally essential mineral elements. USA: Marcel Dekker Inc; 1997.

Olli JJ, Breivik H, Mørkøre T, Ruyter B, Johansen J, Reynolds P, Thorstad O, Berge G. Removal of persistent organic pollutants from Atlantic salmon (Salmo salar L) diets: Influence on growth feed utilization efficiency and product quality. Aquaculture 2010; 310: 145-155. 
Olli JJ, Breivik H, Thorstad O. Removal of persistent organic pollutants in fish oils using short-path distillation with a working fluid. Chemosphere 2013; 92: 273-278.

Olsvik PA, Berg V, Lyche JL. Transcriptional profiling in burbot (Lota lota) from Lake Mjøsa-A Norwegian Lake contaminated by several organic pollutants. Ecotox Environ Safe 2013; 92: 94-103.

Ondarza PM, Gonzalez M, Fillmann G, Miglioranz KSB. Polybrominated diphenyl ethers and organochlorine compound levels in brown trout (Salmo trutta) from Andean Patagonia Argentina. Chemosphere 2011; 83: $1597-1602$.

Ondarza PM, Gonzalez M, Fillmann G, Miglioranza KSB. Increasing levels of persistent organic pollutants in rainbow trout (Oncorhynchus mykiss) following a mega-flooding episode in the Negro River basin Argentinean Patagonia. Sci Total Environ 2012; 419: 233-239.

Ondarza PM, Gonzalez M, Fillmann G, Miglioranza KSB. PBDEs PCBs and organochlorine pesticides distribution in edible fish from Negro River basin Argentinean Patagonia. Chemosphere 2014; 94: 135-142.

Ortiz X, Guerra P, Díaz-Ferreroa J, Eljarrat E, Barceló D. Diastereoisomer- and enantiomer-specific determination of hexabromocyclododecane in fish oil for food and feed. Chemosphere 2011; 82: 739-744.

Pan J, Yang Y-L, Xu Q, Chen D-Z, Xi D-L. PCBs PCNs and PBDEs in sediments and mussels from Qingdao coastal sea in the frame of current circulations and influence of sewage sludge. Chemosphere 2007; 66: 19711982.

Papachlimitzou A, Barber JL, Losada S, Bersuder P, Law RJ. A review of the analysis of novel brominated flame retardants. J Chromatogr A 2012; 1219: 15-28.

Paquotte P, Lem A. Seafood markets and trade: A global perspective and an overview of EU Mediterranean countries. Options Mediterranéennes 2008; 62: 43 - 55.

Parera J, Ábalos M, Santos F:J, Galceran MT, Abad E. Polychlorinated dibenzo-p-dioxins dibenzofurans biphenyls paraffins and polybrominated diphenyl ethers in marine fish species from Ebro River Delta (Spain). Chemosphere 2013; 93: 499-505.

Parmanne R, Hallikainen A, Isosaari P, Kiviranta H, Koistinen J, Laine O, Rantakokko P, Vuorinen PJ, Vartiainen T. The dependence of organohalogen compound concentrations on herring age and size in the Bothnian Sea northern Baltic. Mar Pollut Bull 2006; 52: 149-161.

Peled M, Scharia R, Sondack D. Thermal rearrangement of Hexabromo-cyclododecane (HBCD). In: Desmurs JR Gérard B and Goldstein MJ, editors. Advances in Organobromine Chemistry II. Amsterdam: Elsevier; 1995. p. 92-99.

Peng J-H, Huang C-W, Weng Y-M, Yak H-K. Determination of polybrominated diphenyl ethers (PBDEs) in fish samples from rivers and estuaries in Taiwan. Chemosphere 2007; 66: 1990-1997.

Perelló G, Martí-Cid R, Castell V, Llobet JM, Domingo JL. Concentrations of polybrominated diphenyl ethers hexachlorobenzene and polycyclic aromatic hydrocarbons in various foodstuffs before and after cooking. Food Chem Toxicol 2009; 47: 709-715. 
Pérez-Fuentetaja A, Lupton S, Clapsadl M, Samara F, Gatto L, Biniakewitz R, Aga DS. PCB and PBDE levels in wild common carp (Cyprinus carpio) from eastern Lake Erie. Chemosphere 2010; 81: 541-547.

Pirard C, Pauw E, Focant JF. Suitability of tandem-in-time mass spectrometry for polybrominated diphenylether measurement in fish and shellfish samples: Comparison with high resolution mass spectrometry. J Chromatogr A 2006; 1115: 125-132.

Qin X, Xia X, Li Y, Zhao Y, Yang Z, Fu S, Tian M, Zhao M, Qin Z, Xu X, Yang Y. Ecotoxicological effects of mixed pollutants resulted from e-wastes recycling and bioaccumulation of polybrominated diphenyl ethers in Chinese loach (Misgurnus anguillicaudatus). J Environ Sci 2009; 21: 1695-1701.

Qin YY, Leung CKM, Leung AOW, Zheng JS, Wong MH. Persistent organic pollutants in food items collected in Hong Kong. Chemosphere 2011; 82: 1329-1336.

Qiu Y, Strid A, Bignert A, Zhu Z, Zhao J, Athanasiadou M, Athanassiadis I, Bergman Å. Chlorinated and brominated organic contaminants in fish from Shanghai markets: A case study of human exposure. Chemosphere 2012; 89: 458-466.

Qiu Y-W, Zhang G, Guo L-L, Zheng GJ, Cai S-Q. Bioaccumulation and historical deposition of polybrominated diphenyl ethers (PBDEs) in Deep Bay South China. Marine Environ Res 2010; 70: $219-226$.

Quinete N, Lavandier R, Dias P, Taniguchi S, Montone R, Moreira I. Specific profiles of polybrominated diphenylethers (PBDEs) and polychlorinated biphenyls (PCBs) in fish and tucuxi dolphins from the estuary of Paraíba do Sul River Southeastern Brazil. Mar Pollut Bull 2011; 62: 440-446.

Ramu K, Kajiwara N, Mochizuki H, Miyasaka H, Asante KA, Takahashi S, Ota S, Yeh H-M, Nishida S, Tanabe S. Occurrence of organochlorine pesticides polychlorinated biphenyls and polybrominated diphenyl ethers in deep-sea fishes from the Sulu Sea. Mar Pollut Bull 2006; 52: 1827-1832.

Ramu K, Kajiwara N, Isobe T, Takahashi S, Kim E-Y, Min B-Y, We S-U, Tanabe S. Spatial distribution and accumulation of brominated flame retardants polychlorinated biphenyls and organochlorine pesticides in blue mussels (Mytilus edulis) from coastal waters of Korea. Environ Pollut 2007; 148: 562-569.RC, 1998. Rotterdam convention on the prior informed consent procedure for certain hazardous chemicals and pesticides in international trade. September 10, 1998.

RC, 2011. Rotterdam convention on the prior informed consent procedure for certain hazardous chemicals and pesticides in international trade. October 24, 2011.Recke R, Vetter W. Photolytic transformation of polybrominated biphenyls leading to the structures of unknown hexa- to nonabromo-congeners. J Chromatogr A 2007; 1167: 184-194.

Recke R, Vetter W. Congener pattern of hexabromobiphenyls in marine biota from different proveniences. Sci Total Environ 2008; 393: 358-366.

Remberger M, Sternbeck J, Palm A, Kaj L, Strömberg K, Brorström-Lundén E. The environmental occurrence of hexabromocyclododecane in Sweden. Chemosphere 2004; 54: 9-21. 
Ren G, Wang Z, Yu Z, Wang Y, Ma S, Wu M, Sheng G, Fu J. Primary investigation on contamination pattern of legacy and emerging halogenated organic pollutions in freshwater fish from Liaohe River Northeast China. Environ Pollut 2013; 172: 94-99.

Richardson SD. Environmental Mass Spectrometry: Emerging Contaminants and Current Issues. Analytical Chemistry 2010; 82: 4742-4774.

Richman LA, Kolic T, MacPherson K, Fayez L, Reiner E. Polybrominated diphenyl ethers in sediment and caged mussels (Elliptio complanata) deployed in the Niagara River. Chemosphere 2013; 92: 778-786.

Robson M, Melymuk L, Bradley L, Treen B, Backus S. Wet deposition of brominated flame retardants to the Great Lakes basin - Status and trends. Environ Pollut 2013; 182: 299-306.

Rodil R, Carro AM, Lorenzo RA, Torrijos RC. Selective Extraction of Trace Levels of Polychlorinated and Polybrominated Contaminants by Supercritical Fluid-Solid Phase Microextraction and Determination by Gas Chromatography/Mass Spectrometry Application to Aquaculture Fish Feed and Cultured Marine Species. Analytical Chemistry 2005; 77: 2259-2265.

Rodil R, Carro AM, Lorenzo RA, Cela R. Multicriteria optimisation of a simultaneous supercritical fluid extraction and clean-up procedure for the determination of persistent organohalogenated pollutants in aquaculture samples. Chemosphere 2007; 67: 1453-1462.Roosens L, Dirtu AC, Goemans G, Belpaire C, Gheorghe A, Neels H, Blust R, Covaci A. Brominated flame retardants and polychlorinated biphenyls in fish from the river Scheldt Belgium. Environ Int 2008; 34: 976-983.

Roosens L, Geeraerts C, Belpaire C, Van Pelt I, Neels H, Covaci A. Spatial variations in the levels and isomeric patterns of PBDEs and HBCDs in the European eel in Flanders. Environ Int 2010; 36: 415-423.

Roszko M, Szymczyk K, Jędrzejczak R. Separation of polychlorinated dibenzo-p-dioxins/furans nonortho/mono/di/tri/tetra-ortho-polychlorinated biphenyls and polybrominated diphenyl ethers groups of compounds prior to their determination with large volume injection gas chromatography-Quadrupole ion storage tandem mass spectrometry. Anal Chim Acta 2013; 799: 88-98.

Rotander A, van Bavel B, Rigét F, Auðunsson GA, Polder A, Gabrielsen GW, Víkingsson G, Mikkelsen B, Dam M. Methoxylated polybrominated diphenyl ethers (MeO-PBDEs) are major contributors to the persistent organobromine load in sub-Arctic and Arctic marine mammals 1986-2009. Sci Total Environ 2012; 416: 482489.

Saegusa Y, Fujimoto H, Woo G-H, Inoue K, Takahashi M, Mitsumori K, Hirose M, Nishikawa A, Shibutani M. Developmental toxicity of brominated flame retardants tetrabromobisphenol A and 1256910hexabromocyclododecane in rat offspring after maternal exposure from midgestation through lactation. Reprod Toxicol 2009; 28: 456-467.

Salamova A, Hites RA. Discontinued and alternative brominated flame retardants in the atmosphere and precipitation from the Great lake basin. Environ Sci Technol 2011; 45: 8698-8706.

Sánchez-Avila J, Fernandez-Sanjuan M, Vicente J, Lacorte S. Development of a multi-residue method for the determination of organic micropollutants in water sediment and mussels using gas chromatography-tandem mass spectrometry. J Chromatogr A 2011; 1218: 6799-6811. 
Santín G, Barón E, Eljarrat E, Barceló D. Emerging and historical halogenated flame retardants in fish samples from Iberian rivers. J Hazard Mater 2013; 263: 116-121.

Sapozhnikova Y, Lehotay SJ. Multi-class multi-residue analysis of pesticides polychlorinated biphenyls polycyclic aromatic hydrocarbons polybrominated diphenyl ethers and novel flame retardants in fish using fast low-pressure gas chromatography-tandem mass spectrometry. Anal Chim Acta 2013; 758: 80-92.

Schecter A, Colacino J, Patel K, Kannan K, Yun SH, Haffnerd D, Harris TR, Birnbaum L. Polybrominated diphenyl ether levels in foodstuffs collected from three locations from the United States. Toxicol Appl Pharm 2010; 243: 217-224.

Schmid P, Kohler M, Gujer E, Zennegg M, Lanfranchi M. Persistent organic pollutants brominated flame retardants and synthetic musks in fish from remote alpine lakes in Switzerland. Chemosphere 2007; 67: S16S2.

SCPOP, 2006. Stockholm Convention on Persistent Organic Pollutants. Official Journal of the European Union, L209. July 31, 2006.

SCPOP, 2009. Stockholm Convention on Persistent Organic Pollutants. Adoption of amendments to Annexes A B and C CN5242009TREATIES-4. August 29, 2009.

SCPOP, 2011. Stockholm Convention on Persistent Organic Pollutants. Adoption of an amendment to Annex A CN7032011TREATIES-8. October 27, 2011.SCPOP, 2012. Stockholm Convention on Persistent Organic Pollutants. Proposal to amend Annex A to the Stockholm Convention to be discussed at the sixth meeting of the Conference of the Parties. Geneva, 2012.

Shanmuganathan D, Megharaj M, Chen Z, Naidu R. Polybrominated diphenyl ethers (PBDEs) in marine foodstuffs in Australia: Residue levels and contamination status of PBDEs. Mar Pollut Bull 2011; 63: 154-159.

Shaw SD, Berger ML, Brenner D, Carpenter DO, Tao L, Hong C-S, Kannan K. Polybrominated diphenyl ethers (PBDEs) in farmed and wild salmon marketed in the Northeastern United States. Chemosphere 2008; 71: $1422-1431$.

Shaw SD, Berger ML, Brenner D, Kannan K, Lohmann N, Päpke O. Bioaccumulation of polybrominated diphenyl ethers and hexabromocyclododecane in the northwest Atlantic marine food web. Sci Total Environ 2009; 407: 3323-3329.

Shelver WL, Parrotta CD, Slawecki R, Li QX, Ikonomou MG, Barcelo D, Lacorte S, Rubio FM. Development of a magnetic particle immunoassay for polybrominated diphenyl ethers and application to environmental and food matrices. Chemosphere 2008; 73: S18-S23.

Shen H, Yu C, Ying Y, Zhao Y, Wu Y, Han J, Xu Q. Levels and congener profiles of PCDD/Fs PCBs and PBDEs in seafood from China. Chemosphere 2009; 77: 1206-1211.

Shi T, Chen S-J, Luo X-J, Zhang X-L, Tang C-M, Luo Y, Ma YJ, Wu J-P, Peng X-Z, Mai B-X. Occurrence of brominated flame retardants other than polybrominated diphenyl ethers in environmental and biota samples from southern China. Chemosphere 2009a; 74: 910-916. 
Shi Z-X, Wu Y-N, Li J-G, Zhao Y-F, Feng J-F. Dietary Exposure Assessment of Chinese Adults and Nursing Infants to Tetrabromobisphenol-A and Hexabromocyclododecanes: Occurrence Measurements in Foods and Human Milk. Environ Sci Technol 2009b; 43: 4314-4319.

Sinkkonen S, Rantalainen A-L, Paasivirta J, Lahtiperäa M. Polybrominated methoxy diphenyl ethers (MeOPBDEs) in fish and guillemot of Baltic Atlantic and Arctic environments. Chemosphere 2004; 56: 767-775.

Sioen I, Bilau M, Verdonck F, Verbeke W, Willems JL, De Henauw S, Camp JV. Probabilistic intake assessment of polybrominated diphenyl ethers and omega-3 fatty acids through fish consumption. Mol Nutr Food Res 2008; 52: 250 - 257.

Skinner LC. Distributions of polyhalogenated compounds in Hudson River (New York USA) fish in relation to human uses along the river. Environ Pollut 2011; 159: 2565-2574.

SNUR, 2006. Significant New Use Rule Certain Polybrominated Diphenylethers, 71 Fed Reg 3401534018. June 13, 2006.

SNUR, 2012. Significant New Use Rule Certain Polybrominated Diphenylethers, 77 Fed Reg 1986219864 (to be codified at 40 CFR pts 721795 and 799), DecaBDE Phase-out Initiative EPA. April 2, 2012.

Søfteland L, Petersen K, Stavrum A-K, Wu T, Olsvik PA. Hepatic in vitro toxicity assessment of PBDE congeners BDE47 BDE153 and BDE154 in Atlantic salmon (Salmo salar L). Aquat Toxicol 2011; 105: 246263.

Sørmo EG, Salmer MP, Jenssen BM, Hop H, Bæk K, Kovacs KM, Lydersen C, Falk-Petersen S, Gabrielsen GW, Lie E, Skaare JU. Biomagnification of polybrominated diphenyl ether and hexabromocyclododecane flame retardants in the polar bear food chain in Svalbard Norway. Environ Toxicol Chem 2006; 25: 25022511.

Sørmo EG, Jenssen BM, Lie E, Skaare JU. Brominated flame retardants in aquatic organisms from the North Sea in comparison with biota from the high Arctic marine environment. Environ Toxicol Chem 2010; 28 : 2082-2090.Sprague M, Dick JR, Medina A, Tocher DR, Bell JG, Mourente G. Lipid and fatty acid composition and persistent organic pollutant levels in tissues of migrating Atlantic bluefin tuna (Thunnus thynnus L) broodstock. Environ Pollut 2012; 171: 61-71.

Stephansen DA, Svendsen TC, Vorkamp K, Frier J-O. Changes in patterns of persistent halogenated compounds through a pelagic food web in the Baltic Sea. Marine Environ Res 2012; 73: 17-24.

Strid A, Bruhn C, Sverko E, Svavarsson J, Tomy G, Bergman Å. Brominated and chlorinated flame retardants in liver of Greenland shark (Somniosus microcephalus). Chemosphere 2013; 91: 222-228.

Su G, Liu X, Gao Z, Xian Q, Feng J, Zhang X, Giesy JP, Wei S, Liu H, Yu H. Dietary intake of polybrominated diphenyl ethers (PBDEs) and polychlorinated biphenyls (PCBs) from fish and meat by residents of Nanjing China. Environ Int 2012; 42: 138-143.

Sühring R, Möller A, Freese M, Pohlmann J-D, Wolschke H, Sturm R, Xie Z, Hanel R, Ebinghaus R. Brominated flame retardants and dechloranes in eels from German Rivers. Chemosphere 2013; 90: 118-124. 
Sühring R, Byer J, Freese M, Pohlmann J-D, Wolschke H, Möller A, Hodson PV, Alaee M, Hanel R, Ebinghaus R. Brominated flame retardants and Dechloranes in European and American eels from glass to silver life stages. Chemosphere 2014; 116: 104-111.Sun J, Liu J, Liu Q, Qu G, Ruan T, Jiang G. Sample preparation method for the speciation of polybrominated diphenyl ethers and their methoxylated and hydroxylated analogues in diverse environmental matrices. Talanta 2012; 88: 669-676.

Sun J, Liu J, Liu Y, Jiang G. Hydroxylated and methoxylated polybrominated diphenyl ethers in mollusks from Chinese coastal areas. Chemosphere 2013a; 92: 322-328.

Sun Y, Guo H, Yu H, Wang X, Wu J, Xue Y. Bioaccumulation and physiological effects of tetrabromobisphenol A in coontail Ceratophyllum demersum L. Chemosphere 2008; 70: 1787-1795.

Sun Y-S, Hao Q, Xu X-R, Luo X-J, Wang S-L, Zhang Z-W, Mai B-X. Persistent organic pollutants in marine fish from Yongxing Island South China Sea: Levels composition profiles and human dietary exposure assessment. Chemosphere 2013b; 98: 84-90.

Suominen K, Hallikainen A, Ruokojärvi P, Airaksinen R, Koponen J, Rannikko R, Kiviranta H. Occurrence of PCDD/F PCB PBDE PFAS and organotin compounds in fish meal fish oil and fish feed. Chemosphere 2011; 85: 300-306 .

Swartenbroux F, Albajedo B, Angelidis M, Aulne M, Bartkevics V, Besada V, Bignert A, Bitterhof A, Hallikainen A, Hoogenboom R, Jorhem L, Jud M, Law R, Licht Cederberg D, McGovern E, Miniero R, Schneider R, Velikova V, Verstraete F, Vinas L, Vlad S. Task Group 9 Contaminants in fish and other seafood in: H Piha(Ed) Marine Strategy Framework Directive - Joint Report Joint Research Centre - Scientific and Technical Reports. Italy; 2010. p. 15 - 26.

Szlinder-Richert J, Barska I, Usydus Z, Grabic R. Polybrominated diphenyl ethers (PBDEs) in selected fish species from the southern Baltic Sea. Chemosphere 2010; 78: 695-700.

Szymańska JA, Bruchajzer E, Sporny S, Piotrowski JK. Changes in Selected Indicators of Liver Impairment after Repeated Administration of Mono- and Polybromobenzenes in Mice. B Environ Contam Tox 1998; 61: 22-30.

Szymańska JA, Czerski J, Frydrych B. Tissue concentrations of porphyrins: effects of repeated dosage of selected polybromobenzenes in rats. Organohalogen Compd 2002; 56: 1-4.

Tada Y, Fujitani T, Ogata A, Kamimura H. Flame retardant tetrabromobisphenol A induced hepatic changes in ICR male mice. Environ Toxicol Phar 2007; 23: 174-178.

Takahashi S, Oshihoi T, Ramu K, Isobe T, Ohmori K, Kuboder T, Tanabe S. Organohalogen compounds in deep-sea fishes from the western North Pacific off-Tohoku Japan: Contamination status and bioaccumulation profiles. Mar Pollut Bull 2010; 60: 187-196.

Tapie N, Le Menach K, Pasquaud S, Elie P, Devier MH, Budzinski H. PBDE and PCB contamination of eels from the Gironde estuary: From glass eels to silver eels. Chemosphere 2011; 83: 175-185.

Teuten EL, Xu Li, Reddy CM. Two abundant bioaccumulated halogenated compounds are natural products. Science 2005; 307: 917-920. 
Tlustos C, McHugh B, Pratt I, Tyrrell L, McGovern E. Investigation into levels of dioxins furans polychlorinated biphenyls and brominated flame retardants in fishery produce in Ireland. Marine Environment and Health Series 2007; 26: 1-32.

Toft G, Lenters V, Vermeulen R, Heederik D, Thomsen C, Becher G, Giwercman A, Bizzaro D, Manicardi GC, Spanò M, Rylander L, Pedersen HS, Strucińskik P, Zviezdai V, Bonde JP. Exposure to polybrominated diphenyl ethers and male reproductive function in Greenland Poland and Ukraine. Reprod Toxicol 2014; 43: 17.

Tomko G, McDonald KM. Environmental fate of hexabromocyclododecane from a new Canadian electronic recycling facility. J Environ Manage 2013; 114: 324-327.

Tomy GT, Budakowski W, Halldorson T, Whittle DM, Keir MJ, Marvin C, MacInnis G, Alaee M. Biomagnification of $\alpha$ - and $\gamma$-Hexabromocyclododecane Isomers in a Lake Ontario. Food Web Environ Sci Technol 2004; 38: 2298-2303.

Tomy GT, Palace VP, Pleskach K, Ismail N, Oswald T, Danell R, Wautier K, Evans B. Dietary Exposure of Juvenile Rainbow Trout (Oncorhynchus mykiss) to 12-bis(246-tribromo- phenoxy)ethane: Bioaccumulation Parameters Biochemical Effects and Metabolism. Environ Sci Technol 2007; 41: 4913-4918.

Tomy GT, Pleskach K, Oswald T, Halldorson T, Helm PA, Marvin CH, MacInnis G. Enantioselective bioaccumulation of hexabromocyclododecane and 4 congener-specific accumulation of brominated diphenyl ethers in an 5 Eastern Canadian Arctic marine food web. Environ Sci Technol 2008; 42: 3634-3639.

Törnkvist A, Glynn A, Aune M, Darnerud PO, Ankarberg EH. PCDD/F PCB PBDE HBCD and chlorinated pesticides in a Swedish market basket from 2005 - Levels and dietary intake estimations. Chemosphere 2011; 83: 193-199.

Torre A, Pacepavicius G, Martínez MA, Darling C, Muir D, Sherry J, McMaster M, Alaee M. Polybrominated diphenyl ethers and their methoxylated and hydroxylated analogs in Brown Bullhead (Ameiurus nebulosus) plasma from Lake Ontario. Chemosphere 2013; 90: 1644-1651.

Torres L, Nilsen E, Grove R, Patiño R. Health status of Largescale Sucker (Catostomus macrocheilus) collected along an organic contaminant gradient in the lower Columbia River Oregon and Washington USA. Sci Total Environ 2014; 484: 353-364.

Tue NM, Takahashi S, Suzuki G, Isobe T, Viet PH, Kobara Y, Seike N, Zhang G, Sudaryanto A, Tanabe S. Contamination of indoor dust and air by polychlorinated biphenyls and brominated flame retardants and relevance of non-dietary exposure in Vietnamese informal e-waste recycling sites. Environ Int 2013; 51: 160167.

Turja R, Höher N, Snoeijs P, Baršienė J, Butrimavičienė L, Kuznetsova T, Kholodkevich SV, Devier M-H, Budzinski H, Lehtonen KK. A multibiomarker approach to the assessment of pollution impacts in two Baltic Sea coastal areas in Sweden using caged mussels (Mytilus trossulus). Sci Total Environ 2014; 473-474: 398409. 
Turja R, Soirinsuo A, Budzinski H, Devier MH, Lehtonen KK. Biomarker responses and accumulation of hazardous substances in mussels (Mytilus trossulus) transplanted along a pollution gradient close to an oil terminal in the Gulf of Finland (Baltic Sea). Comp Biochem Phys C 2013; 157: 80-92.

Turyk ME, Bhavsar SP, Bowerman W, Boysen E, Clark M, Diamond M, Mergler D, Pantazopoulos P, Schantz S, Carpenter DO. Risks and benefits of consumption of great lakes fish. Environ Health Persp 2012; 120: 1118.

Ueno D, Alaee M, Marvin C, Muir DCG, Macinnis G, Reiner E, Crozier P, Furdui VI, Subramanian A, Fillmann G, Lam PKS, Zheng GJ, Muchtar M, Razak H, Prudente M, Chung K, Tanabe S. Distribution and transportability of hexabromocyclododecane (HBCD) in the Asia-Pacific region using skipjack tuna as a bioindicator. Environ Pollut 2006; 144: 238-247.

Ueno D Isobe T, Ramu K, Tanabe S, Alaee M, Marvin C, Inoue K, Someya T, Miyajima T, Kodama H, Nakata H. Spatial distribution of hexabromocyclododecanes (HBCDs) polybrominated diphenyl ethers (PBDEs) and organochlorines in bivalves from Japanese coastal waters. Chemosphere 2010; 78: 1213-1219.UN, 2013. United Nations SC-6/13: Listing hexabromocyclododecane, https://treaties.un.org/doc/Publication/CN/2013/CN.934.2013-Eng.pdf [online accessed in May $212014]$.

Unger MA, Harvey E, Vadas GG, Vecchione M. Persistent pollutants in nine species of deep-sea cephalopods. Mar Pollut Bull 2008; 56: 1498-1500.

Usydus Z, Szlinder-Richert J, Adamczyk M. Protein quality and amino acid profiles of fish products available in Poland. Food Chem 2009a; 112: 139-145 .

Usydus Z, Szlinder-Richert J, Polak-Juszczak L, Komar K, Adamczyk M, Malesa-Ciecwierz M, Ruczynska W. Fish products available in Polish market - Assessment of the nutritive value and human exposure to dioxins and other contaminants. Chemosphere 2009b; 74: 1420-1428.

Ven L, Verhoef A, Kuil T, Slob W, Leonards PEG, Visser TJ, Hamers T, Herlin M, Håkansson H, Olausson H, Piersma AH, Vos JG. A 28-day oral dose toxicity study enhanced to detect endocrine effects of hexabromocyclododecane in Wistar rats. Toxicol Sci 2006; 94: 281-292.

Ven L, Kuil T, Verhoef A, Verwer CM, Lilienthal H, Leonards PEG, Schauer UMD, Cantón RF, Litens S, Jong FH, Visser TJ, Dekant W, Stern N, Håkansson H, Slob W, Berg M, Vos JG, Piersma AH. Endocrine effects of tetrabromobisphenol-A (TBBPA) in Wistar rats as tested in a one-generation reproduction study and a subacute toxicity study. Toxicology 2008; 245: 76-89.

Ven L, Kuil T, Leonards PEG, Slob W, Lilienthal H, Litens H, Herlin M, Håkansson H, Cantón RF, Berg M, Visser TJ, Loveren H, Vos JG, Piersma AH. Endocrine effects of hexabromocyclododecane (HBCD) in a onegeneration reproduction study in Wistar rats. Toxicol Lett 2009; 185: 51-62.Verhaert V, Covaci A, Bouillon S, Abrantes K, Musibono D, Bervoets L, Verheyen E, Blust R. Baseline levels and trophic transfer of persistent organic pollutants in sediments and biota from the Congo River Basin (DR Congo). Environ Int 2013; 59: 290302. 
Verslycke TA, Vethaak AD, Arijs K, Janssen CR. Flame retardants surfactants and organotins in sediment and mysid shrimp of the Scheldt estuary (The Netherlands). Environ Pollut 2005; 136: 19-31.

Vetter W, von der Recke R, Herzke D, Nygård T. Natural and man-made organobromine compounds in marine biota from Central Norway. Environ Int 2007; 33: 17-26.

Villaverde-de-Sáa E, Valls-Cantenys C, Quintana JB, Rodil R, Cela R. Matrix solid-phase dispersion combined with gas chromatography-mass spectrometry for the determination of fifteen halogenated flame retardants in mollusks. J Chromatogr A 2013; 1300: 85-94.

Voets J, Talloen W, Tender T, van Dongen S, Covaci A, Blust R, Bervoet L. Microcontaminant accumulation physiological condition and bilateral asymmetry in zebra mussels (Dreissena polymorpha) from clean and contaminated surface waters. Aquat Toxicol 2006; 79: 213-225.

Vorkamp K, Christensen JH, Riget F. Polybrominated diphenyl ethers and organochlorine compounds in biota from the marine environment of East Greenland. Sci Total Environ 2004; 331: 143-155.

Vorkamp K, Thomsen M, Frederiksen M, Pedersen M, Knudsen LE. Polybrominated diphenyl ethers (PBDEs) in the indoor environment and associations with prenatal exposure. Environ Int 2011; 37: 1-10.

Vorkamp K, Bossi R, Bester K, Bollmann UE, Boutrup S. New priority substances of the European Water Framework Directive: Biocides pesticides and brominated flame retardants in the aquatic environment of Denmark. Sci Total Environ 2014; 470-471: 459-468.Vrkoslavová J, Demnerová K, Macková M, Zemanová T, Macek T, Hajšlová J, Pulkrabová J, Hrádková P, Stiborová H. Absorption and translocation of polybrominated diphenyl ethers (PBDEs) by plants from contaminated sewage sludge. Chemosphere 2010; 81: 381-386.

Vuorinen PJ, Keinänen M, Kiviranta H, Koistinen J, Kiljunen M, Myllylä T, Pönni J, Peltonen H, Verta M, Karjalainen J. Biomagnification of organohalogens in Atlantic salmon (Salmo salar) from its main prey species in three areas of the Baltic Sea. Sci Total Environ 2012; 421-422: 129-143.

Vuorinen PJ, Kiviranta H, Koistinen J, Pöyhönen O, Ikonen E, Keinänen M. Organohalogen concentrations and feeding status in Atlantic salmon (Salmo salar L) of the Baltic Sea during the spawning run. Sci Total Environ 2014; 468-469: 449-456.

Wan Y, Jones PD, Wiseman S, Chang H, Chorney D, Kannan K, Zhang K, Hu J-Y, Khim JS, Tanabe S, Lam MHW, Giesy JP. Contribution of synthetic and naturally occurring organobromine compounds to bromine mass in marine organisms. Environ Sci Technol 2010; 44: 6068-6073.

Wang F, Wang J, Dai J, Hu G, Wang J, Luo X, Mai B. Comparative tissue distribution biotransformation and associated biological effects by decabromodiphenyl ethane and decabrominated diphenyl ether in male rats after a 90-day oral exposure study. Environ Sci Technol 2010a; 44: 5655-5660.

Wang H-M, Yu Y-J, Han M, Yang S-W, li Q, Yang Y. Estimated PBDE and PBB congeners in soil from an electronics waste disposal site. B Environ Contam Tox 2009a; 83: 789-793. 
Wang H-S, Du J, Ho K-L, Leung H-M, Lam MH-W, Giesy JP, Wong CK-C, Wong MH. Exposure of Hong Kong residents to PBDEs and their structural analogues through market fish consumption. J Hazard Mater 2011a; 192: 374-380.

Wang J, Lin Z, Lin K, Wang C, Zhang W, Cui C, Lin J, Dong Q, Huang C. Polybrominated diphenyl ethers in water sediment soil and biological samples from different industrial areas in Zhejiang China. J Hazard Mater 2011b; 197: 211-219.

Wang P, Zhang Q, Wang Y, Wang T, Li X, Ding L, Jiang G. Evaluation of Soxhlet extraction accelerated solvent extraction and microwave-assisted extraction for the determination of polychlorinated biphenyls and polybrominated diphenyl ethers in soil and fish samples. Anal Chim Acta 2010b; 663: 43-48.

Wang S, Zhang S, Huang H, Lu A, Ping H. Debrominated hydroxylated and methoxylated metabolism in maize (Zea mays L) exposed to lesser polybrominated diphenyl ethers (PBDEs). Chemosphere 2012; 89: 1295-1301.

Wang S, Zhang S, Huang H, Niu A, Han W. Characterization of polybrominated diphenyl ethers (PBDEs) and hydroxylated and methoxylated PBDEs in soils and plants from an e-waste area China. Environ Pollut 2014; 184: 405-413.

Wang W, Batterman S, Chernyak S, Nriagu J. Concentrations and risks of organic and metal contaminants in Eurasian caviar. Ecotox Environ Safe 2008; 71: 138-148.

Wang Z, Ma X, Lin Z, Na G, Yao Z. Congener specific distributions of polybrominated diphenyl ethers (PBDEs) in sediment and mussel (Mytilus edulis) of the Bo Sea China. Chemosphere 2009b; 74: 896-901.

Wania F, Dugani CG. Assessing the long-range transport potential of polybrominated diphenyl ethers: A comparison of four multimedia models. Environ Toxicol Chem 2003; 22: 1252-1261.

Waszak I, Dabrowska H, Góra H. Bioaccumulation of polybrominated diphenyl ethers (PBDEs) in flounder (Platichthys flesus) in the southern Baltic Sea. Marine Environ Res 2012; 79: 132-141.

Watanabe W, Shimizu T, Sawamura R, Hino A, Konno K, Hirose A, Kurokawa M. Effects of tetrabromobisphenol A a brominated flame retardant on the immune response to respiratory syncytial virus infection in mice. Int Immunopharmacol 2010; 10: 393-397.

Watkins DJ, McClean MD, Fraser AJ, Weinberg J, Stapleton HM, Webster TF. Associations between PBDEs in office air dust and surface wipes. Environ Int 2013; 59: 124-132.

Webster L, Walsham P, Russell M, Hussy I, Neat F, Dalgarno E, Packer G, Scurfield JA, Moffat CF. Halogenated persistent organic pollutants in deep water fish from waters to the west of Scotland. Chemosphere 2011; 83: 839-850.

WHO, 1994. World Health Organisation. International Programme on Chemical Safety (IPCS) Environmental Health Criteria 152 Polybrominated biphenyls WHO. Geneva.

Williams TD, Diab AM, Gubbins M, Collins C, Matejusova I, Kerr R, Chipman JK, Kuiper R, Vethaak AD, George SG. Transcriptomic responses of European flounder (Platichthys flesus) liver to a brominated flame retardant mixture. Aquat Toxicol 2013; 142-143: 45-52. 
Wiseman SB, Wan Yi, Chang H, Zhang X, Hecker M, Jones PD, Giesy JP. Polybrominated diphenyl ethers and their hydroxylated/methoxylated analogs: Environmental sources metabolic relationships and relative toxicities. Mar Pollut Bull 2011; 63: 179-188.

Wit CA, Björklund JA, Thuresson K. Tri-decabrominated diphenyl ethers and hexabromocyclododecane in indoor air and dust from Stockholm microenvironments 2: Indoor sources and human exposure. Environ Int 2012; 39: 141-147.

Wood JD, Richardson RI, Nute GR, Fisher AV, Campo MM, Kasapidou E, Sheard PR, Enser M. Effects of fatty acids on meat quality: a review. Meat Science 2003; 66: 21-32.Wu J-P, Luo X-J, Zhang Y, Luo Y, Chen S-J, Mai BX, Yang Z-Y. Bioaccumulation of polybrominated diphenyl ethers (PBDEs) and polychlorinated biphenyls (PCBs) in wild aquatic species from an electronic waste (e-waste) recycling site in South China. Environ Int 2008; 34: 1109-1113.

Wu J-P, Luo X-J, Zhang Y, Yu M, Chen SJ, Mai B-X, Yang Z-Y. Biomagnification of polybrominated diphenyl ethers (PBDEs) and polychlorinated biphenyls in a highly contaminated freshwater food web from South China. Environ Pollut 2009; 157: 904-909.

Wu J-P, Guan Y-T, Zhang Y, Luo X-J, Zhi H, Chen S-J, Mai B-X. Trophodynamics of Hexabromocyclododecanes and Several Other Non-PBDE Brominated Flame Retardants in a Freshwater Food Web. Environ Sci Technol 2010; 44: 5490-5495.

Wu M, Zuo Z, Li B, Huang L, Chen M, Wang C. Effects of low-level hexabromocyclododecane (HBCD) exposure on cardiac development in zebrafish embryos. Ecotoxicology 2013; 22: 1200-1207.

Wu T, Wang S, Huang H, Zhang S. Diastereomer-specific uptake translocation and toxicity of hexabromocyclododecane diastereoisomers to maize. J Agr Food Chem 2012; 60: 8528-8534.

Xia C, Lam JCW, Wu X, Sun L, Xie Z, Lam PKS. Levels and distribution of polybrominated diphenyl ethers (PBDEs) in marine fishes from Chinese coastal waters. Chemosphere 2011a; 82: 18-24.

Xia C, Lamb JCW, Wu X, Sun L, Xie Z, Lamb PKS. Hexabromocyclododecanes (HBCDs) in marine fishes along the Chinese coastline. Chemosphere 2011b; 82: 1662-1668.

Xian Q, Ramu K, Isobe T, Sudaryanto A, Liu X, Gao Z, Takahashi S, Yu H, Tanabe S. Levels and body distribution of polybrominated diphenyl ethers (PBDEs) and hexabromocyclododecanes (HBCDs) in freshwater fishes from the Yangtze River China. Chemosphere 2008; 71: 268-276.

Xie Z, Ebinghaus R, Lohmann R, Heemken O, Caba A, Püttmann W. Trace determination of the flame retardant tetrabromobisphenol $\mathrm{A}$ in the atmosphere by gas chromatography-mass spectrometry. Anal Chim Acta 2007; 584: 333-342.

Xu J, Gao Z, Xian Q, Yu H, Feng J. Levels and distribution of polybrominated diphenyl ethers (PBDEs) in the freshwater environment surrounding a PBDE manufacturing plant in China. Environ Pollut 2009a; 157: 19111916. 
Xu T, Cho IK, Wang D, Rubio FM, Shelver WL, Gasc AME, Li J, Li QX. Suitability of a magnetic particle immunoassay for the analysis of PBDEs in Hawaiian euryhaline fish and crabs in comparison with gas chromatography/electron capture detection-ion trap mass spectrometry. Environ Pollut 2009b; 157: 417-422.

Xu W, Wang X, Cai Z. Analytical chemistry of the persistent organic pollutants identified in the Stockholm Convention: A review. Anal Chim Acta 2013; 790: 1-13.

Yang Q, Qiu X, Li R, Liu S, Li K, Wang F, Zhu P, Li G, Zhu T. Exposure to typical persistent organic pollutants from an electronic waste recycling site in Northern China. Chemosphere 2013a; 91: 205-211.

Yang R, Jing C, Zhang Q, Wang Z, Wang Y, Li Y, Jiang G. Polybrominated diphenyl ethers (PBDEs) and mercury in fish from lakes of the Tibetan Plateau. Chemosphere 2011; 83: 862-867.

Yang S, Xu F, Zheng B, Wu F, Wang S. Multibiomarker responses upon exposure to tetrabromobisphenol A in the freshwater fish Carassius auratus. Aquat Toxicol 2013b; 142-143: 248-256.

Yang W, Yu Z-Q, Xiang-Fan L, Jia-Liang F, Dong-Ping Z, Guo-Fa R, Guo-Ying S, Jia-Mo F. Qualitative Analysis of Some Emerging Halogenous Pollutions in Fish Sample by Comprehensive Two-Dimensional Gas Chromatography/Time-of-Flight Mass Spectrometry. Chinese J Anal Chem 2012a; 40: 1187-1193.

Yang S-W, Yan Z-G, Xu F-F, Wang S-R, Wu F-C. Development of freshwater aquatic life criteria for Tetrabromobisphenol A in China. Environ Pollut 2012b; 169: 59-63.

Yu H-Y, Guo Y, Bao L-J, Qiu Y-W, Zeng EY. Persistent halogenated compounds in two typical marine aquaculture zones of South China. Mar Pollut Bull 2011b; 63: 572-577.

Yu M, Luo M-Y, Wu J-P, Chen S-J, Mai B-X. Bioaccumulation and trophic transfer of polybrominated diphenyl ethers (PBDEs) in biota from the Pearl River Estuary South China. Environ Int 2009; 35: 1090-1095.

Yu Y-X, Huang N-B, Zhang X-Y, Li J-L, Yu Z-Q, Han S-Y, Lu M-L, Van de Wiele T, Wu M-H, Sheng G-Y, Fu J-M. Polybrominated diphenyl ethers in food and associated human daily intake assessment considering bioaccessibility measured by simulated gastrointestinal digestion. Chemosphere 2011a; 83: 152-160.

Zacs D, Rjabova J, Bartkevics V New perspectives on diastereoselective determination of hexabromocyclododecane traces in fish by ultra high performance liquid chromatography-high resolution orbitrap mass spectrometry. J Chromatogr A 2014; 1130: 30-39.

Zatecka E, Ded L, Elzeinova F, Kubatova A, Dorosh A, Margaryan H, Dostalova P, Peknicova J. Effect of tetrabrombisphenol $\mathrm{A}$ on induction of apoptosis in the testes and changes in expression of selected testicular genes in CD1 mice. Reprod Toxicol 2013; 35: 32-39.

Zhang B-Z, Ni H-G, Guan Y-F, Zeng EY. Occurrence bioaccumulation and potential sources of polybrominated diphenyl ethers in typical freshwater cultured fish ponds of South China. Environ Pollut 2010a; 158: 1876-1882.

Zhang D-P, Zhang X-Y, Yu Y-X, Li J-L, Yu Z-Q, Wu M-H, Fu J-M. Tissue-specific distribution of fatty acids polychlorinated biphenyls and polybrominated diphenyl ethers in fish from Taihu Lake China and the benefitrisk assessment of their co-ingestion. Food Chem Toxicol 2012; 50: 2837-2844. 
Zhang X, Yang F, Luo $\mathrm{C}$, Wen S, Zhang X, Xu Y. Bioaccumulative characteristics of hexabromocyclododecanes in freshwater species from an electronic waste recycling area in China. Chemosphere 2009; 76: 1572-1578.

Zhang Y, Luo X-J, Wu J-P, Liu J, Wang J, Chen S-J, Mai B-X. Contaminant pattern and bioaccumulation of legacy and emerging organhalogen pollutants in the aquatic biota from an e-waste recycling region in South China. Environ Toxicol Chem 2010b; 29: 852-859.

Zhang Y, Sun H, Liu F, Dai Y, Qin X, Ruan Y, Zhao L, Gan Z. Hexabromocyclododecanes in limnic and marine organisms and terrestrial plants from Tianjin China: Diastereomer- and enantiomer-specific profiles biomagnification and human exposure. Chemosphere 2013; 93: 1561-1568.

Zhao A, Liu H, Zhang A, Wang X, Zhang H, Wang H. Effect of BDE-209 on glutathione system in Carassius auratus. Environ Toxicol Phar 2011; 32: 35-39.

Zhao G, Zhou H, Wang D, Zha J, Xu Y, Rao K, Ma M, Huang S, Wang Z. PBBs PBDEs and PCBs in foods collected from e-waste disassembly sites and daily intake by local residents. Sci Total Environ 2009; 407 : $2565-2575$.

Zhao Y, Yang L, Wang Q. Pulsed large volume injection gas chromatography coupled with electron-capture negative ionization quadrupole mass spectrometry for simultaneous determination of typical halogenated persistent organic pollutants. J Am Soc Mass Spectrom 2007; 18: 1375-1386.

Zhong Y, Peng P, Huang W. Transformation of tetrabromobisphenol A in the presence of different solvents and metals. Chemosphere 2012; 87: 1141-1148.

Zhou SN, Reiner EJ, Marvin C, Kolic T, Riddell N, Helm P, Dorman F, Misselwitz M, Brindle ID. Liquid chromatography-atmospheric pressure photoionization tandem mass spectrometry for analysis of 36 halogenated flame retardants in fish. J Chromatogr A 2010; 1217: 633-641.

Zhu LY, Hites RA. Temporal trends and spatial distributions of brominated flame retardants in archived fishes from the Great Lakes. Environ Sci Technol 2004; 38: 2779-2784.

Zhu N, Fu J, Gao Y, Ssebugere P, Wang Y, Jiang G. Hexabromocyclododecane in alpine fish from the Tibetan Plateau China. Environ Pollut 2013; 181: 7-13. 
Figure 1 - Published articles regarding seafood/fish contamination by established and novel brominated flame retardants, from 2004 to 2013. PBDEs, Polybrominated diphenyl ethers; PBBs, Polybrominated biphenyls; HBCDDs, Hexabromocyclododecanes; TBBPA, Tetrabromobisphenol A; DBP, 2,4dibromophenol; TBP, 2,4,6-tribromophenol; HBB, Hexabromobenzene; DBDPE, Decabromodiphenyl ethane, BTBPE, 1,2-Bis(2,4,6-tribromophenoxy)ethane.

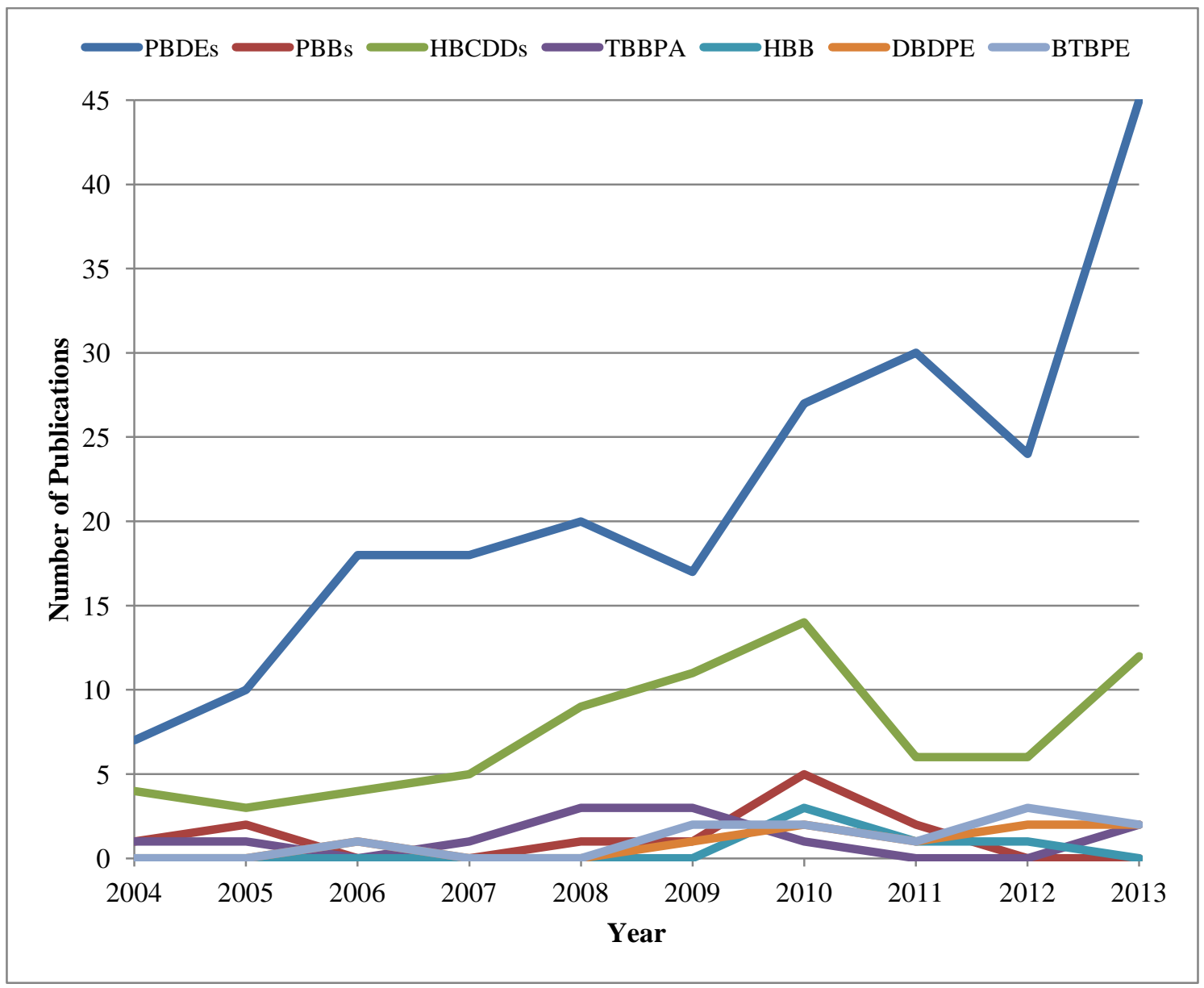


Table 1

\begin{tabular}{|c|c|c|c|c|c|c|c|c|c|}
\hline Common name & $\begin{array}{l}\text { Abbrev } \\
\text { iation }\end{array}$ & $\begin{array}{c}\text { CAS } \\
\text { Number }\end{array}$ & $\begin{array}{c}\text { IUPAC } \\
\text { name }\end{array}$ & Structural formula & $\begin{array}{l}\text { Molecul } \\
\text { ar } \\
\text { formula }\end{array}$ & $\begin{array}{c}\text { Molecu } \\
\text { lar } \\
\text { weight }\end{array}$ & $\begin{array}{l}\text { Log } \\
\mathbf{K}_{\text {ow }}\end{array}$ & $\begin{array}{c}\text { Vapor } \\
\text { pressur } \\
\text { e } \\
(\mathbf{k P a}, \\
\left.\mathbf{2 5}^{\circ} \mathrm{C}\right) \\
\end{array}$ & $\begin{array}{c}\text { Referen } \\
\text { ces }\end{array}$ \\
\hline $\begin{array}{l}\text { Polybrominated } \\
\text { diphenyl ethers }\end{array}$ & PBDEs & - & - & & $\begin{array}{c}\mathrm{C}_{12} \mathrm{H}_{10-\mathrm{x}} \\
\mathrm{Br}_{\mathrm{x}} \mathrm{O} \\
\text { where } \mathrm{x} \\
=1,2, \ldots, \\
10=\mathrm{m}+ \\
\mathrm{n}\end{array}$ & $\begin{array}{c}248.9- \\
959.0\end{array}$ & $\begin{array}{c}6.7_{(x=} \\
3)^{-} \\
9.4\end{array}$ & $\begin{array}{c}3.1 \times \\
10^{-6}(\mathrm{x}=3) \\
-2.2 \times \\
10^{-13}\end{array}$ & $\begin{array}{l}\text { EFSA, } \\
\text { 2011b }\end{array}$ \\
\hline $\begin{array}{l}\text { Polybrominated } \\
\text { biphenyls }\end{array}$ & PBBs & - & - & & $\begin{array}{c}\mathrm{C}_{12} \mathrm{H}_{10-\mathrm{x}} \\
\mathrm{Br}_{\mathrm{x}} \\
\text { where } \mathrm{x} \\
=1,2, \ldots, \\
\begin{array}{c}10=\mathrm{m}+ \\
\mathrm{n}\end{array}\end{array}$ & $\begin{array}{c} \\
234.9- \\
943.0\end{array}$ & $\begin{array}{c}6.5_{(x=}= \\
4)- \\
9.4\end{array}$ & $\begin{array}{c}5.0 \times \\
10^{-7}(\mathrm{x}=4) \\
-3.2 \times \\
10^{-13}\end{array}$ & $\begin{array}{c}\text { EFSA, } \\
2010\end{array}$ \\
\hline $\begin{array}{l}\text { Hexabromocycl } \\
\text { ododecane }\end{array}$ & $\begin{array}{c}\text { HBCD } \\
\text { Ds }\end{array}$ & $\begin{array}{c}\text { 25495- } \\
\text { 98-1 }\end{array}$ & $\begin{array}{c}1,2,5,6,9,10 \\
- \\
\text { hexabromoc } \\
\text { yclododeca } \\
\text { ne }\end{array}$ & & $\begin{array}{c}\mathrm{C}_{10} \mathrm{H}_{14} \mathrm{Br} \\
6\end{array}$ & 613.6 & 6.6 & $\begin{array}{l}1.0 \times \\
10^{-10}\end{array}$ & $\begin{array}{l}\text { EFSA, } \\
2011 d\end{array}$ \\
\hline $\begin{array}{c}\text { Tetrabromobisp } \\
\text { henol A }\end{array}$ & TBBPA & 79-94-7 & $\begin{array}{c}4,4 \text { '- } \\
\text { (propane- } \\
2,2- \\
\text { diyl)bis(2,6- } \\
\text { dibromophe } \\
\text { nol) }\end{array}$ & & $\begin{array}{c}\mathrm{C}_{15} \mathrm{H}_{12} \mathrm{Br} \\
{ }_{4} \mathrm{O}_{2}\end{array}$ & 543.9 & 9.7 & $\begin{array}{c}1.9 \times \\
10^{-8}\end{array}$ & $\begin{array}{l}\text { EFSA, } \\
2011 c\end{array}$ \\
\hline Dibromophenol & DBP & 615-58-7 & $\begin{array}{l}2,4- \\
\text { dibromophe } \\
\text { nol }\end{array}$ & & $\begin{array}{c}\mathrm{C}_{6} \mathrm{H}_{4} \mathrm{Br}_{2} \\
\mathrm{O}\end{array}$ & 251.9 & 3.5 & $\begin{array}{c}3.6 \times \\
10^{-3}\end{array}$ & $\begin{array}{c}\text { EFSA, } \\
2012\end{array}$ \\
\hline $\begin{array}{c}\text { Tribromopheno } \\
1\end{array}$ & TBP & 118-79-6 & $\begin{array}{c}2,4,6- \\
\text { tribromophe } \\
\text { nol }\end{array}$ & & $\begin{array}{c}\mathrm{C}_{6} \mathrm{H}_{3} \mathrm{Br}_{3} \\
\mathrm{O}\end{array}$ & 330.8 & 4.4 & $\begin{array}{c}2.0 \times \\
10^{-4}\end{array}$ & $\begin{array}{l}\text { EFSA, } \\
2012 b\end{array}$ \\
\hline $\begin{array}{l}\text { Hexabromoben } \\
\text { zene }\end{array}$ & HBB & 87-82-1 & $\begin{array}{c}1,2,3,4,5,6- \\
\text { hexabromo } \\
\text { benzene }\end{array}$ & & $\mathrm{C}_{6} \mathrm{Br}_{6}$ & 551.5 & 6.1 & $\begin{array}{c}1.1 \times \\
10^{-7}\end{array}$ & $\begin{array}{l}\text { EFSA, } \\
2011 \mathrm{a}\end{array}$ \\
\hline
\end{tabular}




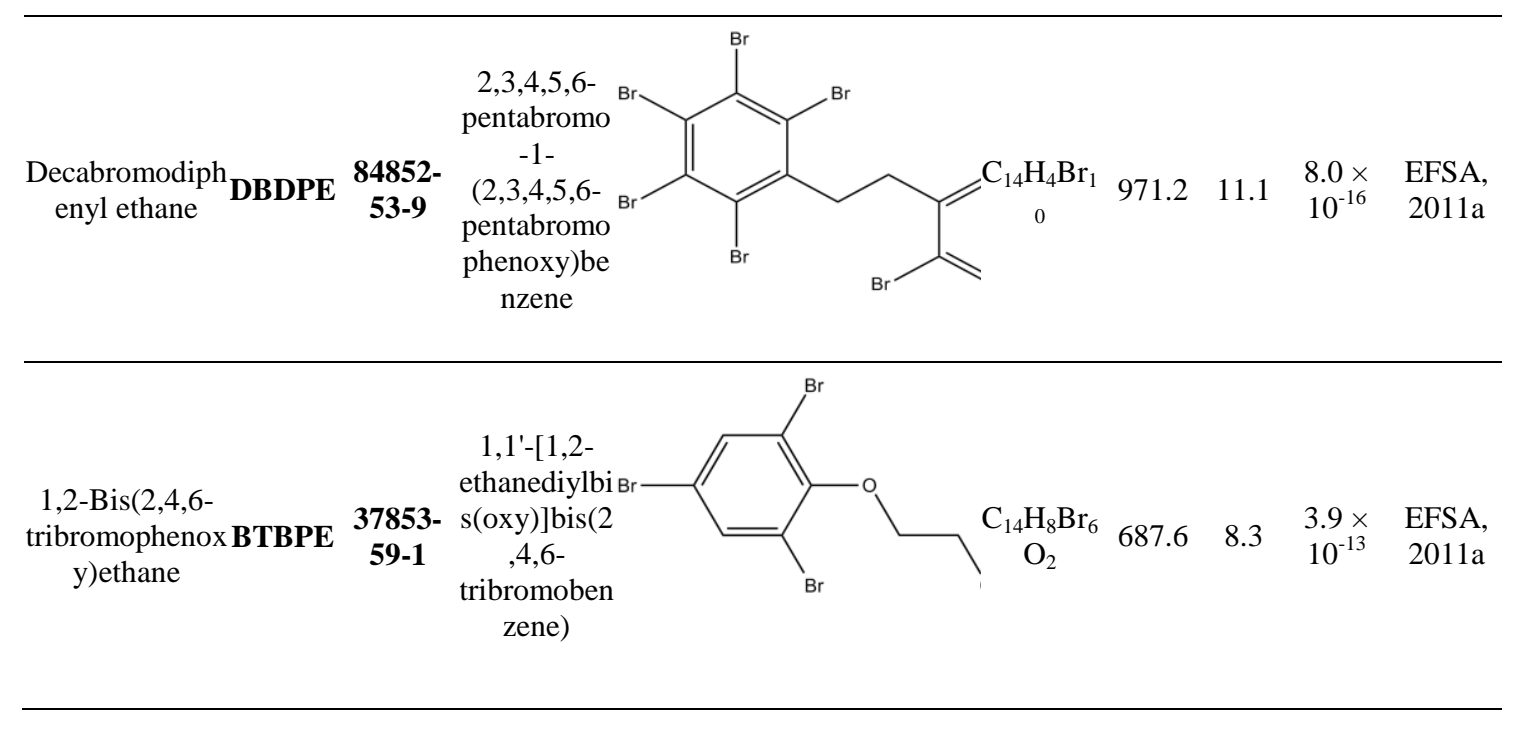

